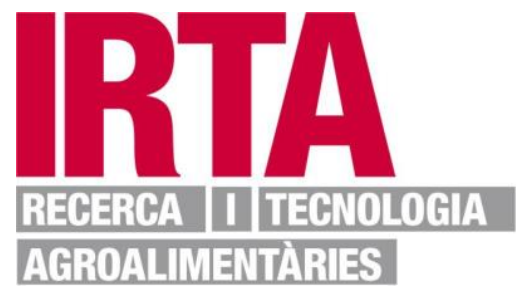

This document is a postprint version of an article published in Innovative Food Science and Emerging Technologies (C) Elsevier after peer review. To access the final edited and published work see https://doi.org/10.1016/j.ifset.2018.12.012

Document downloaded from: 


\section{Strategies to reduce microbial risk and improve quality of fresh and}

2 processed strawberries: A review

3 Tomás Lafarga a, Pilar Colás-Medà a , Maribel Abadias a, Ingrid Aguiló-Aguayo a ,

4 Gloria Bobo ${ }^{a} \&$ Inmaculada Viñas ${ }^{b *}$

5 a IRTA, XaRTA-Postharvest, Parc Científic i Tecnològic Agroalimentari de Lleida, Parc

6 de Gardeny, Edifici Fruitcentre. 25003-Lleida, Catalonia, Spain.

$7 \quad{ }^{\mathrm{b}}$ Food Technology Department, University of Lleida, XaRTA-Postharvest, Agrotecnio

8 Center, Lleida, Spain

9

10 *Corresponding author: Prof. Inmaculada Viñas, (+34) 973702677, ivinas@tecal.udl.cat

13 Abbreviations: AIT: allyl isothiocyanate, CAP: cold atmospheric plasma, CFU: 14 colony-forming units, EFSA: European Food Safety Authority, EOW: electrolyzed 15 oxidizing water, HAV: hepatitis A virus; HDL: high density lipoprotein-cholesterol, 16 HPP: high pressure processing, IPL: intense pulsed light, LAE: lauric arginate ester, 17 LDL: low density lipoprotein-cholesterol, LVA: levulinic acid, MAP: modified 18 atmosphere packaging, MNV-1: murine norovirus 1, NoV: norovirus, PAA: peracetic 19 acid, PEF: pulsed electric field, POD: peroxidase, PPO: polyphenoloxidase, RASFF: 20 Rapid Alert System for Food and Feed, SDS: sodium dodecyl sulphate, TAB: total 21 aerobic bacteria, TMC: total microbial counts, US: ultrasounds, UV: ultraviolet, WHO: 22 World Health Organization, WPL: water-assisted pulsed light, YMC: yeasts and moulds 23 count. 


\section{Abstract}

25 Strawberries are one of the most important fruits in the Mediterranean diet and have 26 been widely investigated for their nutritional and nutraceutical properties. Concern

27 about the safety of fresh and processed strawberries has increased in recent years due to

28 the emergence of several outbreaks of foodborne pathogens linked to their consumption.

29 The use of chlorine as a disinfectant has been identified as a concern due to public

30 health issues and limited efficacy at removing contamination, and preventing cross-

31 contamination. This has led to the development of novel alternatives to chlorine

32 disinfection and thermal treatments, which include, among others, the use of organic

33 acids, high pressure processing, intense pulsed light, or pulsed electric fields. These

34 technologies do not generally affect the nutritional and organoleptic properties of the

35 product and some of these have been reported to stimulate the production of valuable

36 compounds in strawberries and to improve their overall quality.

37

38 Keywords: thermal processing, microbial decontamination, non-thermal processing, chemical 39 decontamination, strawberry, processed fruits 


\section{Introduction}

41 Different organizations including the World Health Organization (WHO) and the

42 European Food Safety Authority (EFSA), as well as governments worldwide,

43 recommend daily consumption of fruit and vegetables as this has been linked to many

44 positive health outcomes (Giampieri, Alvarez-Suarez, \& Battino, 2014; Giampieri et al.,

45 2015; Giampieri, Tulipani, Alvarez-Suarez, Quiles, Mezzetti, \& Battino, 2012).

46 However, despite the well-known benefits derived from consuming raw and minimally

47 processed fruit and vegetables, safety is still an issue of concern (Artes \& Allende, 2014). The concern about microbiological safety of fresh, minimally processed, or frozen fruit has increased in recent years due to the emergence of several outbreaks of

50 foodborne pathogens linked to their consumption and to the presence of chemical

51 contaminants such as pesticides. One of the most recent outbreaks occurred during the last trimester of 2012, when a norovirus (NoV) gastroenteritis outbreak affected over 11,000 people in Germany. Many more people could have been infected as the outbreak vehicle, frozen strawberries imported from China, was identified within a week leading to a timely recall and preventing more than half of the product reaching the market (Bernard et al., 2014).

The strawberry belongs to the genus Fragaria in the Rosaceae. Strawberry consumption has been linked to reduced cholesterol (Basu, Betts, Nguyen, Newman, Fu, \& Lyons, 2014; Basu, Nguyen, Betts, \& Lyons, 2014; Zunino, et al., 2012) and in vivo antioxidant

60 activities (Alvarez-Suarez, et al., 2014; Bialasiewicz et al., 2014). Strawberries are one

61 of the most common and important fruits in the Mediterranean diet and one of the most

62 investigated fruits because of their nutritional and nutraceutical properties (Mezzetti et al., 2014). However, in 2014, the Panel on Biological Hazards of EFSA published a scientific opinion about the risk of Salmonella and NoV in berries, including 
strawberries (EFSA, 2014). EFSA Panel on Biological Hazards concluded that crosscontamination, poor hygiene, or contamination from food handlers, together with the use of contaminated washing water were the main health risks and considered it a priority to carry out more research on decontamination treatments effective against all relevant microbiological hazards including Salmonella and NoV in strawberries.

One of the current problems in the food industry is related to the use of chlorine as a disinfectant, which has been identified as a concern due to public health issues and has already been prohibited in some European countries including Belgium, Denmark, Germany, and the Netherlands (Meireles, Giaouris, \& Simões, 2016). Limited efficacy at removing contamination and preventing cross-contamination, sequestering of chlorine, and residual odour traits are additional limitations of using chlorine for the disinfection of fruit. As a result, chemical and physical strategies which are environmentally friendly and safe have been developed for the disinfection of fruit and vegetables in the food industry. These include the use of novel chemical strategies, which can be liquids such as electrolyzed oxidizing water (EOW) (Rahman, Park, Song, 80 Al-Harbi, \& Oh, 2012) or organic acids (van de Velde, Güemes, \& Pirovani, 2014) or 81 gases such as ozone (Brodowska, Nowak, \& Śmigielski, 2017), chlorine dioxide (Aday \& Caner, 2014), or ethanol vapour (Li, et al., 2018). Physical strategies currently being utilized or studied include high pressure processing (HPP) (Kim, Gil, Kim, \& Cho, 2017) or intense pulsed light (IPL) processing (Duarte-Molina, Gómez, Castro, \& Alzamora, 2016). Some of these strategies are of special interest as previous studies 86 have suggested that their use in the food industry has potential applications beyond 87 microbial decontamination and could improve organoleptic as well as nutritional attributes of fruit- and vegetable-based products (Cao, Huang, \& Chen, 2017; Islam et al., 2016; Valdivia-Nájar, Martín-Belloso, \& Soliva-Fortuny, 2017; Wu et al., 2017; Xu, 
90 Chen, \& Wu, 2016). For example, Duarte-Molina, et al. (2016) demonstrated how

91 treatment of strawberries using IPL reduced the incidence of postharvest moulds during

92 cold storage and confirmed, using transmission electron microscopy, a strengthening of

93 the strawberry cell walls induced by IPL stress, which resulted in no softening of the

94 fruit.

95 The current paper reviews risk mitigation systems for safe and high quality fresh or

96 processed strawberries and discusses how these technologies affect health-promoting

97 phytochemicals found in strawberries. 
99 Despite the health benefits of strawberry consumption, they are generally eaten raw and 100 represent a potential risk for consumers. Fresh and minimally processed fruits are

101 naturally contaminated by diverse microorganisms through different sources, including 102 the field environment, postharvest handling, and processing (Beuchat, 1996). These 103 microbial contaminants could be responsible for the microbial spoilage of strawberries 104 and potential human pathogens have been identified in strawberries. Therefore, their 105 control or elimination is of key importance in order to commercialize safe and healthy 106 products.

$108 \quad 2.1$ Spoilage microorganisms

109 Microorganisms that cause spoilage of strawberries and other fruit represent a huge 110 problem for food processors (Petruzzi, Corbo, Sinigaglia, \& Bevilacqua, 2017). Indeed, 111 strawberry spoilage losses can be as high as $40 \%$ (Luksiene, \& Brovko, 2013).

112 Different strawberry varieties provide diverse ecological niches to microorganisms. The 113 presence, variety, and number of microorganisms also depends on parameters including 114 agronomic practices, geography, weather, harvest, transport, and further handling and 115 processing (Ramos, Miller, Brandão, Teixeira, \& Silva, 2013). However, some mould 116 and bacteria species are more often identified in the surface of strawberries and can be

117 considered as the main microorganisms responsible for spoilage. Grey mould caused by

118 Botrytis cinerea is the principal fungal decay in strawberries and the main contributor to 119 overall postharvest losses (Kader, 1991). Hashmi, East, Palmer, and Heyes (2013) and

120 Tournas, and Katsoudas (2005) identified both, B. cinerea and Rhizopus stolonifer as 121 main spoilage microorganisms in strawberries. $B$. cinerea has been also identified in 122 strawberries grown in varied climates such as, Germany (Leroch, Plesken, Weber, 
123 Kauff, Scalliet, \& Hahn, 2013), Turkey (Ilhan \& Karabulut, 2013), and Brazil (Costa,

124 Rangel, Morandi, \& Bettiol, 2013). Alternaria alternata is together with B. cinerea the 125 most dominant mould in strawberries, which produces a toxin responsible for 126 postharvest black rot (Zhang, Sun, Yang, Chen, Li, \& Zhang, 2015). Other known 127 fungal species include those reported by Wei, Guo, and Lei (2017) who identified 128 Mucor fragilis, Mucor circinelloides, Mucor racemosus, Rhizomucor variabilis and

129 Penicillium spp. as the main spoilage-causing fungi on the surface of strawberries.

130 Several yeasts and bacteria have been also reported in strawberry surfaces. For example,

131 Jensen et al. (2013) identified 22 yeast species from 9 genera, of which species from the

132 genera Candida, Cryptococcus, and Rhodotorula were dominant. In the same study, the 133 authors isolated a large number of bacteria including those from the genera

134 Curtobacterium, Serratia, Pseudomonas, Enterobacter and Rahnella. Previous studies suggested Pseudomonas, Stenotrophomonas, Bacillus, and Arthrobacter as the dominating epiphytic bacteria on strawberry plants - including leaves and flowers

137 (Krimm, Abanda-Nkpwatt, Schwab, \& Schreiber, 2005). Moreover, de Melo Pereira, 138 Magalhães, Lorenzetii, Souza, and Schwan (2012) identified several bacterial species in

139 strawberries including Bacillus subtilis, Enterobacter ludwigii, Lactobacillus 140 plantarum, Pantoea punctata, and Curtobacterium citreum.

\section{$142 \quad 2.2$ Human-pathogenic microorganisms and mycotoxins}

143 As seen before, the epiphytic microbiota of strawberries is diverse. Occasionally, fruits 144 can become contaminated with pathogenic microorganisms while growing, during 145 harvesting, postharvest handling, processing, or during distribution (Beuchat, 1996).

146 Pre-harvest contamination can occur directly or indirectly via animals, insects, water, 147 soil, dirty equipment, and human handling. During harvesting, postharvest handling and 
148 processing, microorganisms could reach the product by human handling, dirty

149 equipment, utensils, or containers.

150 Limited information about the incidence and survival of pathogens in fresh, minimally

151 processed, and frozen strawberries is currently available. Jensen et al. (2013) isolated

152 potential opportunistic bacterial species including Rahnella aquatilis, Hafnia alvei,

153 Chromobacterium violaceum and different Staphylococcus species. These bacteria were

154 reported to cause different infectious human diseases. In the same study, the authors

155 detected a number of yeasts that have been associated with infectious diseases including

156 Cryptococcus neoformans, Candida famata, and Candida inconspicua. In addition,

157 Johannessen et al. (2015) did not find Campylobacter, Salmonella, and shiga-toxin

158 producing E. coli (STEC) in Norwegian strawberries. Similarly, neither Salmonella nor

159 STEC were detected in samples of strawberries from primary production in Belgium

160 (Delbeke et al., 2015). An E. coli O157:H7 outbreak took place in the United States in

1612011 with 15 cases, including 2 deaths (Laidler et al., 2013).

162 Besides pathogenic bacteria, viruses are also of great concern in fresh and processed

163 strawberries (mainly in frozen strawberries). NoV and hepatitis A virus (HAV) are the

164 main foodborne viruses associated with consumption of fresh and frozen berries 165 worldwide (Palumbo, Harris, \& Danyluk, 2016). A huge outbreak of NoV linked to 166 consumption of frozen strawberries from China affected nearly 11,000 people in

167 Germany in 2012 (Bernard et al., 2014). In 2016, a multistate outbreak of hepatitis A

168 linked to frozen strawberries affected 143 persons, 56 of them were hospitalized (CDC,

169 2016). Recently, a foodborne outbreak also caused by HAV subtype 1B in frozen

170 strawberries from Poland was reported in the European Rapid Alert System for Food

171 and Feed (RASFF) portal (RASFF, 2018a), which affected 13 people in Sweden

172 (RASFF, 2018b). Various berries are increasingly being recognized as vehicles for 
173 enteric viruses. Indeed, Baert et al. (2011) reported that the prevalence of NoV in soft 174 red fruits was $34.5 \%(\mathrm{~N}=29)$ and $6.7 \%(\mathrm{~N}=150)$ of the samples tested in Belgium and

175 France, respectively. Li, Butot, Zuber, PROFER, and Uyttendaele (2018) analysed 2015

176 samples of (frozen) berries (including strawberries) for the presence of HAV, NoV GI

177 and GII. Results demonstrated that 7 of the berry samples were positive for virus

$178(0.3 \%)$. In the case of strawberries, 1 out of 918 samples contained NoV GII and 1 was

179 positive for HAV ( $\mathrm{Li}$ et al., 2018). Macori et al. (2018) evaluated the same virus in 75

180 berry samples from primary production but the survey did not include strawberries. No

181 viruses were found.

182 Some of the fungi isolated from strawberries, such as Penicillium spp., Alternaria spp., 183 and Rhizopus spp. are known as potential mycotoxin producers. Little information is

184 known about the presence of mycotoxins in strawberries. In this sense, in strawberries 185 produced in Turkey, Demirci, Arici, and Gumus (2003) found patulin in 8 out of 10 186 samples analysed (3.2-572 ng/g). On the contrary, Jensen et al. (2013) did not detect 187 mycotoxins in mature strawberries but some strains of Penicillium expansum and 188 Aspergillus niger isolated from strawberries were able to produce high amount of 189 mycotoxins when incubated in strawberries at $25^{\circ} \mathrm{C}$. Juan, Oueslati, and Mañes (2016) 190 evaluated Alternaria mycotoxins in strawberries stored at different temperatures and 191 found alternariol in $42 \%$ of samples stored at 22 and in $37 \%$ of samples stored at $6{ }^{\circ} \mathrm{C}$, 192 with concentrations ranging between 26 and $752 \mathrm{ng} / \mathrm{g}$. In addition, alternariol methyl 193 ether was found mainly in stored samples at $6{ }^{\circ} \mathrm{C}$ for more than 28 days and no samples 194 contained tentoxin.

195 Finally, concerning the prevalence of parasites on strawberries, no studies have been 196 found. However, in the US and Canada, there have been several outbreaks of 197 Cyclospora cayetanensis linked to the consumption of raspberries (Palumbo et al., 
198 2014). In 2016, the Netherlands notified a parasitic infestation with microsporidia

199 (presence of Giardia parasite) in strawberries from Spain through the RASFF portal 200 (RASFF, 2018c).

201 Concerning the survival of foodborne pathogens, E. coli O157:H7 and Salmonella 202 survived but did not grow on the surface of fresh strawberries at 24 and $5{ }^{\circ} \mathrm{C}$ and also 203 survived in frozen strawberries for periods of greater than 1 month (Knudsen, 204 Yamamoto, \& Harris, 2001). More recently, Delbeke et al. (2014) assessed the survival 205 of Salmonella and E. coli $\mathrm{O} 157: \mathrm{H7}$ on strawberries during a 1-week storage period at 206 refrigerated and ambient temperatures. Results highlighted the importance of avoiding 207 contamination at cultivation and postharvest as washing had only a limited effect and 208 both pathogens survived during storage. 
211 As mentioned previously, the use of chlorine as a disinfectant has already been

212 prohibited in some European countries (Meireles et al., 2016). Although several

213 chemical strategies have been studied, those which showed bigger potential for their use

214 for the decontamination of fresh or minimally processed fruit are shown in Figure 1.

215 Chemical strategies are generally used in whole fruit before their commercialization or 216 before processing in order to reduce the initial microbial load of the strawberries. Acidic

217 EOW is produced by electrolysis of water containing dissolved sodium chloride and has

218 been regarded as a safe and effective antimicrobial agent by the WHO. Over the last

219 decade several studies have reported the bactericidal effect of EOW and demonstrated

220 its effect on a variety of microorganisms in different foods including poultry (Rahman

221 et al., 2012), shrimp (Xie, Sun, Pan, \& Zhao, 2012), and lettuce (Forghani et al., 2013).

222 This strategy also showed potential for being used in strawberries (Table 1). Indeed,

223 Guentzel, Callan, Lam, Emmons, and Dunham (2011) suggested that acidic EOW could

224 be used for the disinfection of strawberry plants against $B$. cinerea in the field and

225 Hung, Tilly, and Kim (2010) suggested that acidic EOW was either more or as effective

226 as chlorinated water in killing E. coli $\mathrm{O} 157: \mathrm{H} 7$ cells. In that study, the authors observed

227 reductions of $E$. coli $\mathrm{O} 157: \mathrm{H} 7$ ranging between $0.6-0.9,1.0-1.5$, or 1.2-1.5 log colony

228 forming units (CFU)/g when strawberries were dipped in deionized water, EOW, or

229 chlorinated water for 1 or 5 min at $4{ }^{\circ} \mathrm{C}$. Hung et al. (2010) also observed an effect of

230 temperature on the inactivation studies of E. coli $0157: \mathrm{H} 7$. Indeed, reductions were

231 significantly lower at $24{ }^{\circ} \mathrm{C}$ when compared to $4{ }^{\circ} \mathrm{C}$ and ranged between $0.3-0.9$, 0.6-

232 1.3, and 1.0-1.4 log CFU/g when dipped in deionized water, acidic EOW, or chlorinated

233 water, respectively. One of the main advantages of chemical treatments is that they can 
234 be used alone or in combination with physical treatments such as ultrasounds (US) or

235 water-assisted ultraviolet (UV) irradiation, generally obtaining synergistic or additive

236 effects. However, these effects need to be studied for each food matrix and treatment

237 combinations as combining physical and chemical strategies can also result in

238 antagonist effects.

239 Ozone, a powerful oxidant, has emerged as one of the most promising chemical

240 methods for the preservation of food products and it is highly suitable for fruit and

241 vegetables including strawberries (Tzortzakis \& Chrysargyris, 2017). Table 1 lists

242 recent studies which evaluated the effect of ozone in gas or aqueous phase for

243 disinfecting and extending the shelf life of strawberries. For example, Alexandre,

244 Brandão, and Silva (2012) assessed the effect of ozone in aqueous solution at a

245 concentration of $0.3 \mathrm{ppm}$ on the microbial loads and quality attributes of fresh

246 strawberries. Ozone treatment, which was compared to other physical and chemical

247 strategies, provided the best results in terms of reductions of microbial loads, namely

248 total mesophiles, and yeasts and moulds counts (YMC), when samples were kept at

249 room temperature and did not affect the overall quality of the strawberries. Treatment

250 conditions are of key importance and need to be calculated for each product as ozone

251 can affect the quality of fresh strawberries (Aday \& Caner, 2014; Aday, Büyükcan,

252 Temizkan, \& Caner, 2014). Ozone treatments can be used alone or in combination with

253 other novel strategies such as sonication. Indeed, Aday and Caner (2014) evaluated the

254 effect of ozone at a concentration of $0.075 \mathrm{ppm}$ alone or in combination with US and

255 demonstrated that although ozone alone significantly reduced the physical deterioration

256 and spoilage of strawberries, increasing their shelf life, a combination of both strategies

257 was more effective. For example, the initial $a^{*}$ value of the strawberries in that study

258 was 34.3 and decreased to $30.1,31.2$ and 32.3 during a 4-week storage period in 
samples left untreated, treated with $0.075 \mathrm{ppm}$ of ozone alone or combined with US,

260 respectively. The authors of that study suggested that the combination of ozone and US

261 maintained the phenolic content and inhibited the colour change chemically better when

262 compared to ozone or US alone. Ozone has been also used for the removal of fungicides

263 and insecticides. Indeed, Lozowicka, Jankowska, Hrynko, and Kaczynski (2015)

264 obtained reductions ranging from 36.1 to $75.1 \%$ in the concentration of 16 pesticides

265 (10 fungicides and 6 insecticides) after immersion of strawberries in ozone, in aqueous

266 phase $\left(20^{\circ} \mathrm{C}, 1 \mathrm{mg} / \mathrm{L}\right)$, for processing times ranging from 1 to $5 \mathrm{~min}$. Even higher

267 reductions were reported by Heleno, De Queiroz, Neves, Freitas, Faroni, and De

268 Oliveira (2014) who obtained a 95\% reduction in the concentration of difenoconazole

269 residue after exposure of contaminated strawberries to ozone gas at concentrations 270 ranging from 0.0 to $0.8 \mathrm{mg} / \mathrm{L}$ for $1 \mathrm{~h}$.

271 Organic acids or chlorine dioxide have also been evaluated as potential substitutes for

272 sodium hypochlorite (Table 1). For example, Aday, Buyukcan, and Caner (2013)

273 studied the effect of chlorine dioxide in combination with modified atmospheric

274 packaging (MAP) at concentrations of 3, 6, and $9 \mathrm{ppm}$ on the overall quality of fresh

275 strawberries and demonstrated a significant reduction on the respiration rate as well as

276 an increase of the shelf life. Although results obtained so far suggest chlorine dioxide as

277 an excellent alternative to chlorine, some contradictory results have been published. For

278 example, Arango, Rubino, Auras, Gillett, Schilder, and Grzesiak (2016) treated

279 strawberries with continuously generated chlorine dioxide gas at concentrations ranging

280 from 0.01 to $5.00 \mathrm{mg} / \mathrm{L}$ and durations ranging from 7 to $1000 \mathrm{~min}$. The authors

281 observed that treatments had a minimal effect at delaying the growth rate of $B$. cinerea

282 at 4 or $22{ }^{\circ} \mathrm{C}$ and suggested that chlorine dioxide treatments were not enough to extend

283 the shelf life of strawberries. Although the antimicrobial effect of peracetic acid (PAA) 
284 is well known, a number of studies suggested that treatment using PAA, depending on

285 the concentration, could result in a loss of quality in strawberries. For example, van de

286 Velde, Piagentini, Güemes, and Pirovani (2013) observed reductions of 30 and 37\% in

287 the total anthocyanin and ascorbic acid content, respectively when dipping two varieties

288 of strawberries in $80 \mathrm{mg} / \mathrm{L}$ for $2 \mathrm{~min}$. In order to optimize the disinfection process, van

289 de Velde, et al. (2014) developed a model to evaluate the microbial count reduction

290 under specific PAA concentration, temperature, and treatment time of fresh-cut

291 strawberries. Treatment conditions obtained to maximize the total microbial count

292 (TMC) reduction were $100 \mathrm{ppm}$ at $24{ }^{\circ} \mathrm{C}$ for $50 \mathrm{~s}$. However, those conditions resulted in

293 the appearance of off-odours and off-flavours as well as low retention of anthocyanins

294 and ascorbic acid. In that same study, treatment conditions obtained to maximize

295 anthocyanin and ascorbic acid retention, with a 2-log CFU/g reduction in the TMC,

296 were $20 \mathrm{ppm}$ at $18{ }^{\circ} \mathrm{C}$ for $52 \mathrm{~s}$. The authors of that study suggested the latter conditions

297 to fresh-cut strawberries disinfection because of acceptable TMC reductions together

298 with higher retention of total anthocyanins and ascorbic acid as well as better sensory

299 attributes and economic convenience.

300 Overall, based on the studies published to date, reductions of microorganisms obtained

301 by different chemical alternatives are not so different from those obtained with sodium

302 hypochlorite. It has to be taken into account that long processing times that have been

303 studied are not feasible for practical application. PAA is easy to use and control, while

304 ozone has some concerns due to legal limits in ambient and some problems to control its

305 concentration in washings. However, ozone has the advantage of availability of

306 generators and lack of disinfection by products. Chlorine dioxide has some persisting

307 concerns over chlorite residues and some bleaching action that could affect product

308 quality. 


\section{Physical decontamination of strawberries and strawberry-derived products}

$310 \quad$ 4.1 Effect of thermal and non-thermal strategies on microorganisms

311 Physical methods for food preservation are those that utilize physical treatments to

312 inhibit, destroy, or remove undesirable microorganisms without involving antimicrobial

313 additives. Table 2 lists previous works which studied novel physical technologies which

314 can be used to improve quality and to reduce the microbial load of strawberries and

315 strawberry-derived products. These can be divided into those that involve heating and

316 novel non-thermal treatments such as HPP, pulsed electric fields (PEFs), cold

317 atmospheric plasma (CAP), or those shown in Figure 1. Although some of these

318 techniques can cause a moderate temperature elevation in the food matrix, the increase

319 in temperature is not their main mechanism of action. These technologies can also be

320 divided into those that can be used on processed strawberry-derived products such as

321 jams, juices, or purees and those which aim to be used on fresh and minimally

322 processed strawberries.

\section{$323 \quad$ 4.1.1 Thermal processing}

324 The basic purpose of thermal processing of foods is to reduce microbial and enzymatic 325 activity and to produce physical and chemical changes to make food meet a quality

326 standard. Heat processing is most commonly used in the fruit processing industry to 327 ensure safety and stability of juices, nectars, purées, and jams. The heating process 328 should affect the properties of the product as little as possible keeping prices low.

329 Over the last decades a number of novel heating technologies with shorter start-up 330 times, faster heating, greater energy efficiency, small footprint, and improved 331 organoleptic and nutritional quality of the end product have been developed and these

332 include microwave processing and ohmic heating. Microwave heating has gained 333 special interest in food processing due to its ability to obtain high temperatures, reduce 
334 processing time, and result in a more uniform heating (Stratakos, Delgado-Pando,

335 Linton, Patterson, \& Koidis, 2015). This technology has been efficiently used for the 336 treatment and optimization of decontamination strategies of strawberries and

337 strawberry-based products.

338 For fresh and minimally processed strawberries, mild heat treatments are more 339 appropriate, due to the changes that high temperatures could cause to the fruit. Indeed,

340 Fang, Pengyu, and Xiaohu (2013) suggested that a combination of hot water $\left(40{ }^{\circ} \mathrm{C}, 5\right.$

$341 \mathrm{~min})$, microwave processing, and the use of a composite coating on strawberries was the

342 best processing option to prolong shelf life. Microwaves have been also used alone or in

343 combination with vacuum as a novel method for drying strawberries obtaining high

344 quality products in terms of appearance, colour, and texture (Bórquez, Melo, \&

345 Saavedra, 2015) and extending the shelf life of the dried product (Bruijn et al., 2016).

\section{$346 \quad$ 4.1.2 Non-thermal technologies}

347 The use of heat through thermal processing operations including blanching, 348 pasteurization, and sterilization is still being used as a common practice by food 349 manufacturers. However, as indicated before, these technologies are either undesirable 350 or cannot be used for certain foods such as fresh produce.

351 HPP is an innovative but industrially consolidated technology for processing a wide 352 range of food products and represents an ideal alternative to heat processing. One of the 353 main advantages of this technology is extending the shelf life while retaining the 354 sensory characteristics of fresh foods. Disadvantages of this technology include that it 355 cannot operate in continuous mode and that it cannot be used on whole fruit without 356 modifying quality attributes such as texture. However, several studies have 357 demonstrated the antimicrobial potential of HPP on strawberries. For example, 358 Marszałek, Mitek, and Skąpska (2015b) showed how HPP at 500 MPa reduced the CFU 
of YMC in strawberry puree from 4.6- and 3.8-log CFU/g to less than 1-log CFU/g at

360 both, 0 and $50{ }^{\circ} \mathrm{C}$. In that same study, treatment at $200 \mathrm{MPa}$ also resulted in lower yeast 361 and mould counts with reductions of 2.6- and 0.5-log CFU/g, respectively. Hsu, Sheen,

362 Sites, Huang, and Wu (2014) obtained a reduction of E. coli O157:H7 greater than 5-log

$363 \mathrm{CFU} / \mathrm{g}$ after treatment of strawberry puree at 250 and $350 \mathrm{MPa}$ for $5-30 \mathrm{~min}$ at $10{ }^{\circ} \mathrm{C}$.

364 At those conditions, the E. coli $\mathrm{O} 157: \mathrm{H} 7$ counts were below the detection limit (1.5-log

365 CFU/g). Similar results were obtained by Huang, Ye, and Chen (2013), who eliminated

366 E. coli $\mathrm{O} 157: \mathrm{H} 7$ and Salmonella spp. from strawberry puree after processing at 450

$367 \mathrm{MPa}$ during 2 min at $21^{\circ} \mathrm{C}$. Research has focused mainly on how HPP causes bacterial

368 and fungal inactivation. However, HPP can even cause damage to viruses by damaging

369 the virus envelope preventing their particles binding to cells or even by a complete

370 dissociation of the virus particles (Considine, Kelly, Fitzgerald, Hill, \& Sleator, 2008).

371 Huang, Li, Huang, and Chen (2014) recently suggested that HPP of strawberries and strawberry purée was efficient in inactivating murine norovirus 1 (MNV-1). In that study, MNV-1 was very resistant to pressure under the dry state condition, but became sensitive to pressure under the wet state condition and the efficacy of HPP inactivation

375 increased with decreasing initial sample temperature. A treatment time of 2 min was needed to achieve a $4.3 \log$ reduction of MNV-1 in puree at $350 \mathrm{MPa}$, while 4 min were needed to obtain the same level of reduction at $300 \mathrm{MPa}$. Inactivation curves were almost linear with $\mathrm{R}^{2}$ value of 0.99 . In addition, the calculated $\mathrm{D}$ values for whole strawberries and strawberry puree were similar and calculated as $0.86 \mathrm{~min}$. In that same

380 study, after processing, samples were frozen and stored at $-20{ }^{\circ} \mathrm{C}$ for 28 days and the authors observed additional 0.4 and $0.6 \log$ reductions of MNV-1 for samples treated at 300 and $350 \mathrm{MPa}$, respectively. Similar results were obtained by Kovač, Diez-Valcarce,

383 Raspor, Hernández, and Rodríguez-Lázaro (2012) in strawberry puree. 
384 Table 2 describes major findings on the potential of PEFs for being used to control

385 microorganisms in processed strawberry-derived products. Microbial inactivation by

386 PEFs occurs due to the electrical breakdown of cell membranes caused by the build-up

387 of electrical charges at the cell membrane that ends with the cell membrane disruption

388 (Odriozola-Serrano, Aguiló-Aguayo, Soliva-Fortuny, \& Martín-Belloso, 2013). PEFs

389 consist of very short pulses $(\mu \mathrm{s})$ of electricity to liquid foods placed between two

390 electrodes. Therefore, this technology could be used for decontamination of strawberry

391 juices or purees and not for the whole fruit. Mosqueda-Melgar, Raybaudi-Massilia, and

392 Martín-Belloso (2008) studied the effect of PEFs on the S. enteritidis and E. coli

393 O157:H7 populations inoculated in strawberry juice and concluded that microbial

394 reductions increased when treatment time was higher, showing a logarithmic behaviour.

395 Maximum bacterial inactivation was calculated as 4.43- and 5.46-log CFU/g for $S$.

396 enteriditis and E. coli $\mathrm{O} 157: \mathrm{H} 7$, respectively and were obtained operating at $1700 \mu \mathrm{s}$

397 and $100 \mathrm{~Hz}$. In a more recent study, Gurtler, Bailey, Geveke, and Zhang (2011)

398 obtained inactivations of E. coli $\mathrm{O} 157: \mathrm{H} 7$ of 2.86-, 3.12-, and 3.79-log CFU/g at

399 temperatures of 45,50 , and $55{ }^{\circ} \mathrm{C}$, respectively. The authors of this study also

400 demonstrated that the preservatives sodium benzoate, potassium sorbate, and citric acid

401 induced sub-lethal injury and enhanced PEF inactivation of E. coli O157:H7 and non-

402 pathogenic $E$. coli in strawberry juice.

403 Methods based on the antimicrobial effects of UV irradiation have also been extensively

404 studied. This technology can be used for both fresh and processed strawberries.

405 However, turbidity, suspended solids, and absorbing compounds are key parameters

406 which affect the potential of this technology to disinfect liquid products (Selma,

407 Allende, López-Gálvez, Conesa, \& Gil, 2008) and because of the intense colour of

408 strawberries, this could be a disadvantage. However, Bhat, and Stamminger (2015) 
observed a 2-log reduction in the total aerobic bacteria (TAB) plate counts as well as in

410 total YMC after exposure of strawberry juice to UV radiation (254 $\mathrm{nm}$ ) for 15-60 min.

411 Similar results were reported by Keyser, Müller, Cilliers, Nel, and Gouws (2008) after

412 UV radiation of strawberry juice as described in Table 2. UV light inactivation could

413 also be used for the inactivation of $\mathrm{NoV}$ as previous studies demonstrated that this

414 technology was efficient in inactivating HAV, Aichi virus A, and feline calicivirus on

415 whole strawberries (Fino \& Kniel, 2008). Water-assisted pulsed light (WPL) treatments

416 have also been used for the inactivation of MNV-1. Indeed, Huang and Chen (2015)

417 studied the effect of WPL in combination with $1 \%$ hydrogen peroxide or $100 \mathrm{ppm}$

418 sodium dodecyl sulphate (SDS) on the inactivation of E. coli O157:H7, Salmonella, and

419 MNV-1 in fresh strawberries. The authors of that study reported a reduction in the $E$.

420 coli O157:H7 and Salmonella counts of 2.4- and 4.5-log CFU/g after WPL treatment for

$42160 \mathrm{~s}$. Photosensitization is a novel non-thermal and environmentally friendly technology

422 which involves the administration of photoactive compounds and visible light. This

423 strategy can also be utilized for microbial decontamination of strawberries. Indeed,

424 Luksiene and Paskeviciute (2011) studied the potential of chlorophyllin-based

425 photosensitization to control microbial contamination of strawberries. Strawberries were

426 inoculated with Listeria monocytogenes, soaked in $1 \mathrm{mM}$ chlorophyllin for $5 \mathrm{~min}$ and

427 illuminated for 30 min with visible light. The authors of that study observed 86 and

$42897 \%$ inhibition in naturally occurring yeasts/moulds and mesophiles, respectively and

429 the shelf life of the strawberries was extended by 2 days.

430 US is one of the newest non-thermal technologies to extend the shelf life of fruit. The 431 efficacy of this strategy depends on several parameters including wave frequency, 432 power, and treatment time (de São José, de Andrade, Ramos, Vanetti, Stringheta, \& 433 Chaves, 2014). This strategy has been studied as an alternative to prevent microbial 
434 spoilage of both fresh strawberries and processed strawberry-derived products. Table 2

435 lists several studies which used this technology alone or in combination with chemical 436 sanitizers over the last 5 years. For example, Aday, Temizkan, Büyükcan, and Caner 437 (2013) evaluated the effect of different US powers (30, 60, and $90 \mathrm{~W}$ ) during 5 or 10 438 min on the quality of fresh strawberries. Results demonstrated a significant decrease in 439 the appearance of mould during storage and no differences were observed between 440 samples treated at 30,60, or $90 \mathrm{~W}$. Similar results were obtained by Gani et al. (2016), 441 who demonstrated that the bacterial count decreased from 5.9- to 3.9-log CFU/g while 442 the yeast and mould count decreased from 4.8- to 3.5-log CFU/g after US processing $443(33 \mathrm{kHz}, 60 \mathrm{~W})$ of fresh strawberries. Antimicrobial effect of US has been attributed to 444 two main causes, cavitation and the formation of free radicals which result in thinning 445 and disruption of cell wall structures, pore formation and cell membrane disruption and 446 DNA injuries with produce breakages and fragmentation (de São José et al., 2014). This 447 technology can be used in combination with other chemical or physical strategies such 448 as heat, in a process known as thermosonication (São José \& Vanetti, 2015).

449 The lethal capabilities of CAP have now been amply studied on a wide variety of 450 microorganisms including biofilm formers and bacterial spores. Although this 451 technology is relatively new and there are limited numbers of reports based on CAP 452 decontamination of fresh produce, Table 2 lists examples of studies which evaluated the 453 potential of this technology for the disinfection of strawberry. Overall, antimicrobial 454 efficacy of this technology varies depending on several factors including the system 455 used to produce the plasma, gas composition, and electrode configuration as well as 456 type of bacteria and substrate (Ziuzina, Patil, Cullen, Keener, \& Bourke, 2014). 
459 Blanching, pasteurization, and sterilization can degrade nutritionally important

460 phytochemicals (Lafarga, Bobo, Viñas, Collazo, \& Aguiló-Aguayo, 2018; Nayak, Liu,

$461 \&$ Tang, 2015). Although novel non-thermal technologies can also have an effect on the

462 concentration of health-promoting compounds such as anthocyanins, overall, results

463 obtained so far suggest that if a loss of phytochemicals is produced after non-thermal

464 processing, this would be smaller compared to that obtained after a traditional thermal

465 treatment (Marszałek, et al., 2015b; Marszałek, Woźniak, Kruszewski, \& Skąpska,

466 2017). The phytochemical content and quality of fresh and processed strawberries

467 depends on several factors including season, maturity, variety, and processing

468 conditions including treatment intensity and duration (Ban, et al., 2018; Oszmiański,

469 Lachowicz, Gorzelany, \& Matłok, 2018; Salvador, Rocha, \& Silvestre, 2015; Šamec,

470 Maretić, Lugarić, Mešić, Salopek-Sondi, \& Duralija, 2016; Xie, et al., 2015). This has

471 to be calculated for each process independently and needs to be considered when

472 calculating the dietary intake of these compounds from processed strawberries and

473 strawberry-based products.

\section{$474 \quad$ 4.2.1 Thermal processing}

475 According to Patras, Brunton, O'Donnell, and Tiwari (2010), it is not possible to predict

476 the effect of thermal treatment on retention of bioactive compounds, and it is necessary

477 to evaluate each case individually. In addition, besides some mild treatments which do

478 not significantly affect the texture of whole fruit, thermal processes are generally used

479 for juices, jams, or purees. Previous studies suggested that microwave heating might

480 change the phytochemical content and the overall quality of foods to a lesser extent as

481 opposed to conventional heating. For example, Marszałek, Mitek, and Skąpska (2015a)

482 compared the effect of conventional heating and heating using a continuous flow

483 microwave on the safety, shelf life, and quality of strawberry purée. Continuous 
microwave treatment $(2.45 \mathrm{GHz}, 63 \mathrm{~A}, 20 \mathrm{~kW})$ at 80 or $120{ }^{\circ} \mathrm{C}$ during 7 or $10 \mathrm{~s}$ resulted

485 in being significantly less destructive for phenolic compounds, flavonoids,

486 anthocyanins, and vitamin $\mathrm{C}$ when compared to the conventional thermal treatment (90

$487{ }^{\circ} \mathrm{C}$ during $15 \mathrm{~min}$ ). Although some changes in colour were detected, these were barely 488 visible and the overall quality of the purée was not affected. Inactivation of 489 polyphenoloxidase (EC 1.14.18.1; PPO) and peroxidase (EC 1.11.1.7; POD) together 490 with microbial decontamination is one of the main goals of fruit processing. Marszałek, 491 et al. (2015a) did not observe a complete inactivation of PPO and POD after microwave 492 processing of strawberries.

493 Although the concept of ohmic heating is not new, this technology has recently gained 494 new interest because the products obtained using it are generally of better quality than 495 those obtained using conventional heating technologies (Castro, Teixeira, Salengke, 496 Sastry, \& Vicente, 2004). This technology was used for the dehydration of strawberries 497 obtaining beneficial effects on their microstructure and on the kinetics of water loss 498 (Moreno, et al., 2012a) and also on the overall quality and shelf life of the product 499 (Moreno, et al., 2012b).

500 In addition, as mentioned previously, mild heat treatments can also be used to increase 501 the shelf life of strawberries and strawberry-derived products. Caleb et al. (2016) 502 investigated the impact of mild hot water dipping $\left(35\right.$ and $\left.45^{\circ} \mathrm{C}\right)$ during 5 or $10 \mathrm{~min}$ on 503 the physicochemical quality (mass loss and transpiration, surface color, texture, total 504 soluble solids, titrated acidity and $\mathrm{pH}$ ), individual sugars, antioxidant activity, 505 anthocyanin and visual quality of freshly harvested strawberries stored at $4^{\circ} \mathrm{C}$. The 506 microbial quality was not investigated but results showed that hot water treatment at 45 $507{ }^{\circ} \mathrm{C}$ for $5 \mathrm{~min}$ had no detrimental effects and best maintained quality attributes of 508 strawberries and prevented incidence of decay. 
510 In recent years, consumers have become more aware of the influence of food on health

511 and well-being and there has been a growth in the demand for high quality, minimally

512 processed foods that are both nutritious and tasty. This has led to the development of

513 novel non-thermal technologies which ensure the safety and stability of foods while

514 minimizing the degradation of nutritious and tasty compounds.

515 Strategies which are used on liquid strawberry-derived products such as juices are 516 mainly HPP and PEFs. Although treatment of strawberries using HPP can improve the 517 sensory quality of products when compared to a conventional thermal processing, HPP 518 can degrade total polyphenols, anthocyanins, and vitamin C in strawberries (Marszałek, 519 et al., 2015b). Verbeyst, Bogaerts, Van der Plancken, Hendrickx, and Van Loey (2013) 520 proposed a model to describe the degradation of ascorbic acid during thermal processing 521 at atmospheric pressure and at $700 \mathrm{MPa}$ and concluded that the combination of HPP 522 with heat enhanced the thermal degradation of ascorbic acid in both aerobic and anaerobic conditions. The authors suggested that the use of HPP could be advantageous

524 on the pasteurization level but not on the sterilization level of strawberries, even if times

525 could be reduced. HPP has been shown to reduce the activity of enzymes including PPO

526 and POD in strawberries previously (Marszałek, et al., 2015b). However, HPP-induced 527 protein denaturation can be reversible depending on several factors including 528 temperature, treatment time, intensity, and also the type of protein (Considine, et al., 529 2008). Sulaiman and Silva (2013) reported that treatment of strawberries at $600 \mathrm{MPa}$ 530 resulted in high inactivation of PPO, although some residual activity was observed after $53115 \mathrm{~min}$.

532 PEFs showed excellent antimicrobial effects on strawberry juices and purees (Table 2). 533 In addition, Mosqueda-Melgar, Raybaudi-Massilia, and Martín-Belloso (2012) recently 
534 reported no differences in the aroma and colour of strawberry juice and PEF processed

535 juice $(35 \mathrm{kV} / \mathrm{cm}$ for $1,700 \mu$ s in bipolar $4 \mu$ s pulses at $100 \mathrm{~Hz}$ ). In addition, although the

536 authors of that study observed a decrease in taste and overall acceptance after

537 processing, the observed decrease was smaller when compared to the one observed after

538 thermal processing at $90{ }^{\circ} \mathrm{C}$ for $1 \mathrm{~min}$. Odriozola-Serrano, Soliva-Fortuny, and Martín-

539 Belloso (2008) observed how PEF treated strawberry juice (35 kV/cm for $1,700 \mu \mathrm{s}$ in

540 bipolar $4 \mu$ s pulses at $100 \mathrm{~Hz}$ ) maintained higher amounts of polyphenols including

541 anthocyanins, and ellagic and coumaric acid when compared to the thermally treated

542 juice $\left(90^{\circ} \mathrm{C}\right.$ for $\left.1 \mathrm{~min}\right)$. However, the higher content of health-related compounds was

543 not reflected in a higher antioxidant capacity.

544 UV-C processing of strawberries is thought to be effective not only in extending shelf

545 life and improving organoleptic properties but also in increasing the content of health-

546 promoting phytochemicals. For example, Xie, et al. (2015) studied the effect of UV-C

547 on the antioxidant capacity and phytochemical profiles of three different strawberry

548 cultivars and, although processing did not affect the antioxidant capacity of the fruit, the

549 phytochemical content of the cultivar 'Albion' significantly increased after processing.

550 A recent study carried out by Oviedo-Solís, et al. (2017) reported an in vitro increase in

551 the antioxidant activity, attributed to an increase in the content of polyphenols

552 (flavonoids, anthocyanins, fisetin, and pelargonidine), of strawberries after being

553 irradiated with UV-C at $1.2 \mathrm{~W} / \mathrm{m}^{2}$ during $16.5 \mathrm{~min}$. In addition, in that same study, the

554 authors assessed the in vivo antioxidant potential of freeze-dried irradiated and non-

555 irradiated strawberries using high fat diet-induced rats and demonstrated how the

556 irradiated strawberries were better than the control, reducing the oxidative damage in

557 brain, probably due to the increased content of flavonoids. However, these results

558 contrast with other studies which suggested a decrease in the antioxidant potential and 
559 in the phytochemical content of strawberries after UV-C processing. Indeed, some

560 studies suggested a reduction in the content of ascorbic acid, anthocyanins, and total 561 phenols together with a decrease in antioxidant activity after UV processing (Bhat, et

562 al., 2015). Other quality parameters such as the sugar content or the content of organic 563 acids were not affected after UV-C processing of strawberries either (Xie, et al., 2016).

564 There is no way of predicting these effects of UV processing on the quality of fruit and 565 these need to be assessed for each product independently. Based on the results 566 previously reported and described in the current paper, it seems that the effect of UV-C 567 processing on the levels of bioactive compounds in strawberries depends on several 568 factors which include variety, climate, season, as well as processing parameters such as 569 intensity or duration. However, further studies are needed in order to obtain robust 570 conclusions. Only few studies have assessed the effect of IPL processing on 571 strawberries. Duarte-Molina, et al. (2016) recently observed a cell wall stregthening 572 after processing although weight loss through storage was similar in untreated and 573 treated samples. In that study, IPL treatment delayed the onset of infection of 574 strawberries, which was visually inspected. Moreover, Luksiene, Buchovec, and 575 Viskelis (2013) did not observe any improvement in the organoleptic and nutritional 576 quality of strawberries after IPL treatment, besides a reduction in the microbial load and 577 a 2-day increase of the products shelf life. Further studies are needed in order to assess 578 its potential for improving quality in strawberries. Overall, results reported so far 579 suggest no significant effects on the overall quality besides microbial decontamination.

580 However, further studies are needed in order to assess if this technology could be used 581 to increase quality of fresh or processed strawberries. Photosensitization resulted in 582 increased antioxidant capacity of strawberries previously (Luksiene, et al., 2011). 
583 However, further studies are needed in order to assess the real effect of this technology

584 on the quality of fresh and processed strawberries.

585 Aday, Temizkan, Büyükcan, and Caner (2013) evaluated the effect of different US

586 powers $(20 \mathrm{kHz} ; 30,60$, or $90 \mathrm{~W})$ during 5 or $10 \mathrm{~min}$ on the quality of strawberries. The

587 authors of this study concluded that while US power of $90 \mathrm{~W}$ resulted in negative

588 effects on the fruits ' quality (reduction in lightness, firmness, and red hue), power levels

589 between 30 and $60 \mathrm{~W}$ improved colour and firmness retention and enhanced shelf life.

590 Similar results were obtained by Gani, et al. (2016), who demonstrated that US (33 kHz,

$59160 \mathrm{~W}$ ) enhanced antioxidant activity and facilitated better retention of $\mathrm{pH}$, colour, and

592 texture. Tomadoni, Cassani, Viacava, Moreira, and Ponce (2017) recently obtained an

593 increase in both, polyphenol content and antioxidant activity after sonication of

594 strawberry juice at $40 \mathrm{kHz}$ for 10 or $30 \mathrm{~min}$, when compared to thermally treated juice

595 at $90{ }^{\circ} \mathrm{C}$ for $1 \mathrm{~min}$. Similar results were obtained by Bhat and Goh (2017) who obtained

596 a significant enhancement in bioactive compounds after processing for $30 \mathrm{~min}$. In a

597 different study, Sulaiman, Soo, Farid, and Silva (2015) inactivated PPO in strawberries

598 by thermosonication, the combination of US and heat, during $10 \mathrm{~min}$ at $32{ }^{\circ} \mathrm{C}$. Although

599 the quality attributes of the samples were not assessed, much lower processing

600 temperatures were needed when compared to thermal processing alone, and the authors

601 suggested that a potentially better fruit quality could be obtained. US shows a big

602 potential for being used in the food industry not only for enzymatic and microbial

603 inactivation but also for the extraction of valuable phytochemicals which could be

604 further included into foods as functional ingredients (Sun, Zhai, Zhang, Qiu, Ou, \& Bai, 605 2014).

606 Although some studies have suggested an increase of the anthocyanin content of some

607 fruits after treatment using CAP (Kovačević, Putnik, Dragović-Uzelac, Pedisić, Režek 
608 Jambrak, \& Herceg, 2016), so far, no significant effects have been observed on the

609 nutritional quality of processed strawberries. This technology would allow to retain the

610 quality of fresh strawberries while it significantly improves their shelf life. For example,

611 Misra, et al. (2014a) observed no adverse effects on respiratory rates, texture, or colour

612 of strawberries after processing and Misra, et al. (2014b), who evaluated the use of CAP

613 induced in MAP gases for fresh strawberries in a closed package, observed how besides

614 extending shelf life, strawberries treated and stored in a high oxygen gas mixture

615 showed more favourable respiration rates and a higher firmness than the control over a

$61624 \mathrm{~h}$ period. 


\section{5. Conclusions}

618 A large number of chemical and physical alternatives to chlorine have been reported

619 over the last couple of decades. Some of these showed promising results and could be as

620 efficient as chlorine, or even more, in eliminating microorganisms from the surface of

621 strawberries. Overall, the use of chemical and physical non-thermal strategies seems to

622 result in better retention of antioxidants and phytochemicals in strawberries when

623 compared to conventional thermal treatments. These technologies can be divided into

624 two groups, based on their use in fresh or minimally processed strawberries or in liquid

625 strawberry-derived products such as purees, nectars, or juices. From those technologies

626 which can be used on fresh or minimally processed samples, IPL and UV-C irradiation

627 showed the best results as besides microbial inactivation, several reports highlighted an

628 increase in the nutritional value of strawberries after processing. In addition, PEFs

629 showed promising results and could be an alternative to thermal pasteurization of

630 strawberry-derived products. From those chemical strategies studied over the last years,

631 ozone either in the gaseous or liquid phase showed microbial reductions (including

632 human pathogens) comparable to those obtained using chlorine. Acidic EOW and PAA

633 treatments also resulted in promising results and show potential for being used as

634 substitutes of chlorine in the food industry. Most of these technologies are

635 environmentally friendly, economically viable, are accepted by consumers, and show

636 potential for their use during the industrial production of safe, nutritious, and tasty

637 strawberry-based products. 
639 This work forms part of the FRESAFE Research Project (Mitigation Strategies to 640 Reduce the Microbial Risks and Improve the Quality and Safety of Frozen and Ready641 to-Eat Strawberries), funded by the Spanish Ministry of Economy, Industry, and 642 Competitiveness (AGL2016-78086-R). This work was also supported by the CERCA 643 Programme of Generalitat de Catalunya. T. Lafarga is in receipt of Juan de la Cierva 644 contract awarded by the Spanish Ministry of Economy, Industry, and Competitiveness 645 (FJCI-2016-29541). I. Aguiló-Aguayo thanks the Spanish Ministry of Economy, 646 Industry and Competitiveness and the European Social Fund for the Postdoctoral Senior 647 Grant Ramon y Cajal (RYC-2016-19949).

648

649 Conflict of interests

650 The authors declare no conflict of interests 


\section{Figures}

Figure 1. Summary of alternatives to chlorine and conventional thermal pasteurization which could be used to improve safety, quality, and shelf life of strawberries

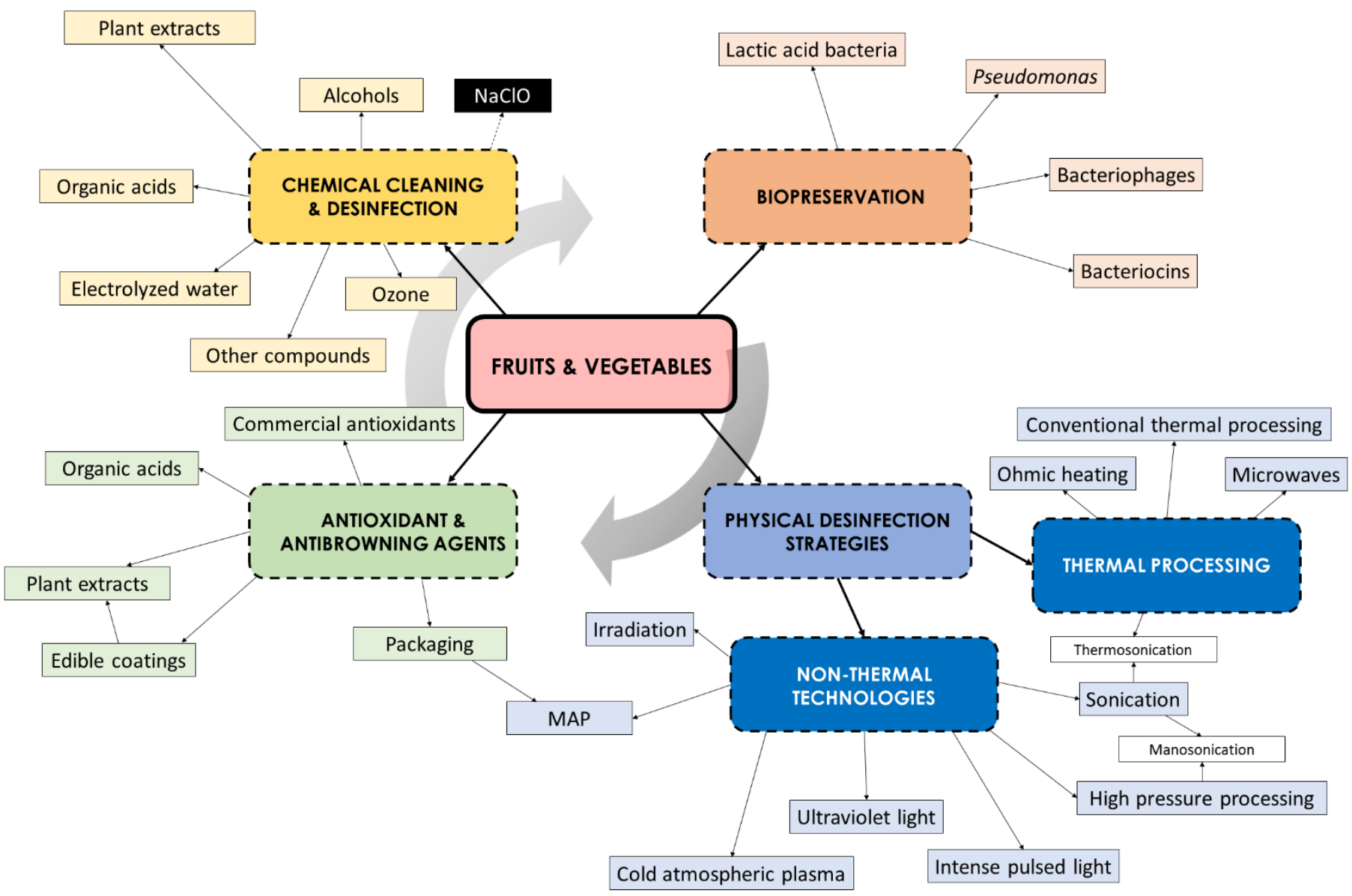




\section{Table 1. Overview of chemical strategies applied for the control of microorganisms on strawberries and strawberry-derived products.}

\begin{tabular}{|c|c|c|c|c|c|}
\hline $\begin{array}{l}\text { Chemicals } \\
\text { evaluated }\end{array}$ & Treatment conditions & Microorganisms studied & Food matrix & Main outcomes & Reference \\
\hline $\begin{array}{l}\text { Acidic EOW } \\
\text { and chlorinated } \\
\text { water }\end{array}$ & $\begin{array}{l}\text { Acidic EOW: } 23 \text { and } 55 \\
\text { mg/L of residual chlorine } \\
\text { Chlorinated water: } 100 \\
\text { mg/L of residual chlorine } \\
\begin{array}{l}\text { Exposure time: } 1 \text { or } 5 \\
\text { min }\end{array}\end{array}$ & E. coli $\mathrm{O} 157: \mathrm{H} 7$ & $\begin{array}{l}\text { Inoculated } \\
\text { strawberries and } \\
\text { broccoli }\end{array}$ & $\begin{array}{l}\text { Inactivation of } E \text {. coli } \mathrm{O} 157: \mathrm{H} 7 \text { was temperature and time } \\
\text { dependent. Increasing soaking times from } 1 \text { to } 5 \mathrm{~min} \\
\text { reduced populations of the pathogen by } 0.1-\text { to } 0.8-\mathrm{log} \\
\text { CFU/g regardless of treatment solution. }\end{array}$ & (Hung et al., 2010) \\
\hline Acidic EOW & $\begin{array}{lr}\text { Available } & \text { chlorine } \\
\text { concentration: } & 34.3 \\
\mathrm{mg} / \mathrm{mL} & \end{array}$ & $\mathrm{TAB}$ and $\mathrm{YMC}$ & $\begin{array}{l}\text { Fresh fruits } \\
\text { including } \\
\text { strawberries }\end{array}$ & $\begin{array}{l}\text { Treatment using acidic EOW resulted in approximately } \\
0.9-\log \text { reductions for both TAB and YMC. }\end{array}$ & $\begin{array}{l}\text { (Ding, Ge, Shi, Xu, } \\
\text { Jones, \& Liu, 2015) }\end{array}$ \\
\hline EOW & 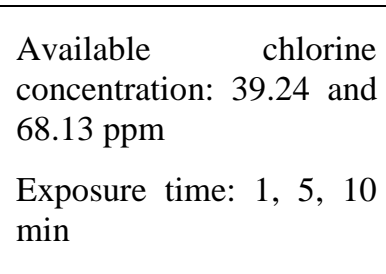 & $\begin{array}{l}\text { Mesophilic aerobic } \\
\text { bacteria and YMC in un- } \\
\text { inoculated samples. E. } \\
\text { coli O157:H7 and } \\
\text { L.monocytogenes } \\
\text { artificially inoculated }\end{array}$ & Strawberries & $\begin{array}{l}\text { Aerobic mesophiles were reduced more than } 2-\log \mathrm{CFU} / \mathrm{g} \\
\text { after washing for } 10 \text { or } 15 \mathrm{~min} \text { in EOW prepared from } \\
0.10 \%(\mathrm{w} / \mathrm{v}) \mathrm{NaCl} \text { solution }(68.1 \mathrm{ppm}) . \mathrm{NaOCl} \text { and EOW } \\
\text { solutions demonstrated a comparable antimicrobial effect } \\
\text { against } L \text {. Monocytogenes and E. coli } \mathrm{O} 157: \mathrm{H} 7 \text {. }\end{array}$ & $\begin{array}{l}\text { (Udompijitkul, } \\
\text { Daeschel, \& Zhao, } \\
\text { 2007) }\end{array}$ \\
\hline $\begin{array}{l}\text { Ozone, } \\
\text { chlorinated } \\
\text { water, and } \\
\text { hydrogen } \\
\text { peroxide }\end{array}$ & $\begin{array}{l}\text { Ozone: } 0.3 \mathrm{ppm} \\
\text { Chlorine: } 200 \mu \mathrm{g} / \mathrm{mL} \\
\text { Hydrogen peroxide: } 1 \\
\text { and } 5 \% \\
\text { Exposure time: } 2 \mathrm{~min}\end{array}$ & Total mesophiles, YMC & Fresh strawberries & $\begin{array}{l}\text { Strawberries washed with hydrogen peroxide solutions at } \\
5 \text { and } 1 \% \text { had the highest total mesophiles reduction } \\
\text { measured as } 2.2-\text { and } 1.5-\log \text { unit reductions, respectively. } \\
\text { On average, a } 1.2-\log \text { unit reductions occurred when } \\
\text { samples were washed with aqueous ozone solutions. } \\
\text { However, ozone treatment maintained the lowest total } \\
\text { mesophiles load after storage for } 4 \text { days at } 4{ }^{\circ} \mathrm{C} \text {. }\end{array}$ & (Alexandre et al., 2012) \\
\hline Ozone & $\begin{array}{l}\text { Concentration: } \quad 0.075 \text {, } \\
0.150 \text {, and } 0.250 \mathrm{ppm}\end{array}$ & Moulds & Fresh strawberries & $\begin{array}{l}\text { All ozone treatments prevented mould growth during } \\
\text { storage. However, the } 0.250 \mathrm{ppm} \text { ozone treatment caused }\end{array}$ & $\begin{array}{l}\text { (Aday, Büyükcan, } \\
\text { Temizkan, \& Caner, }\end{array}$ \\
\hline
\end{tabular}




\begin{tabular}{|c|c|c|c|c|c|}
\hline & $\begin{array}{l}\text { Exposure time: } 2 \text { and } 5 \\
\text { min }\end{array}$ & & & $\begin{array}{l}\text { loss of strawberry quality due to high ozone concentration. } \\
\text { Ozone could be applied to extend the shelf life of } \\
\text { strawberries by at least } 3 \text { weeks under refrigerated } \\
\text { conditions. }\end{array}$ & 2014) \\
\hline Ozone & $\begin{array}{l}\text { (i) Continuous ozone } \\
\text { flow }(5 \%) \text { for } 2-64 \mathrm{~min} \text {; } \\
\text { (ii) Pressurizer ozone ( } 83 \\
\mathrm{kPa} \text { ) for } 2-64 \mathrm{~min} \text {; (iii) } \\
\text { Continuous ozone for } 64 \\
\text { min followed by } \\
\text { pressurized ozone for } 64 \\
\text { min; (iv) vacuum } \\
\text { followed by } 64 \text { min of } \\
\text { pressurized ozone. }\end{array}$ & $\begin{array}{l}\text { E. coli } \mathrm{O} 157: \mathrm{H} 7 \text { and } S \text {. } \\
\text { enterica }\end{array}$ & $\begin{array}{l}\text { Inoculated } \\
\text { strawberries }\end{array}$ & $\begin{array}{l}\text { Continuous ozone followed by pressurized ozone showed } \\
\text { the highest reductions of } S \text {. enterica }(2.6-\log \text { reductions) } \\
\text { and E. coli O157 H:7 ( } 2.9-\log \text { reductions). Continuous } \\
\text { ozone flow, pressurized ozone and vacuum followed by } \\
\text { pressurized ozone treatments after } 64 \mathrm{~min} \text { reduced } S \text {. } \\
\text { enterica population by } 0.9-, 2.2-\text { and } 1.7-\log \text { units, and } E \text {. } \\
\text { coli O157H:7 by } 1.8-, 2.3-\text { and } 0.9-\log \text { reductions, } \\
\text { respectively. }\end{array}$ & $\begin{array}{l}\text { (Bialka \& Demirci, } \\
\text { 2007) }\end{array}$ \\
\hline Ozone & $\begin{array}{l}\text { Gaseous ozone at } 6 \% \\
\mathrm{~W} / \mathrm{w}, 10,20,30,40 \mathrm{~min}\end{array}$ & MNV-1 and Tulane virus & $\begin{array}{l}\text { Inoculated } \\
\text { lettuce/strawberries }\end{array}$ & $\begin{array}{l}\text { Gaseous ozone efficacy was dose and time dependent. } \\
\text { After } 40 \text { min, ozone completely inactivated NoV in liquid } \\
\text { media and reduced it on strawberries surfaces }\end{array}$ & $\begin{array}{l}\text { (Predmore, Sanglay, } \\
\text { Li, \& Lee, 2015) }\end{array}$ \\
\hline $\begin{array}{l}\text { Chlorine } \\
\text { dioxide }\end{array}$ & $\begin{array}{l}\text { Concentration: } 10 \mathrm{mg} / \mathrm{L} \\
\text { Exposure time: } 3 \mathrm{~min}\end{array}$ & $\begin{array}{l}\text { E. coli } \mathrm{O} 157: \mathrm{H} 7, \quad S . \\
\text { enterica, } \\
\text { L. monocytogenes, TAB, } \\
\text { and YMC }\end{array}$ & $\begin{array}{l}\text { Inoculated } \\
\text { tomatoes, } \\
\text { cantaloupes, and } \\
\text { strawberries }\end{array}$ & $\begin{array}{l}\text { Nearly a } 5-\log \mathrm{CFU} / \mathrm{cm}^{2} \text { Salmonella reduction was found } \\
\text { on tomatoes, cantaloupe, and strawberries, while a 3-log } \\
\mathrm{CFU} / \mathrm{cm}^{2} \text { reduction was observed for E. coli and Listeria } \\
\text { on all produce surfaces. E. coli and Listeria appeared to be } \\
\text { more resistant to chlorine dioxide as compared to } \\
\text { Salmonella spp. }\end{array}$ & $\begin{array}{l}\text { (Trinetta, Linton, \& } \\
\text { Morgan, 2013) }\end{array}$ \\
\hline $\begin{array}{l}\text { Chlorine } \\
\text { dioxide }\end{array}$ & $\begin{array}{l}\text { Concentration: } \quad 0.5-5.0 \\
\mathrm{mg} / \mathrm{L})\end{array}$ & $\begin{array}{l}\text { E. coli } \quad \mathrm{O} 157: \mathrm{H} 7, \\
\text { L. monocytogenes, } \\
\text { S. enterica, }\end{array}$ & $\begin{array}{l}\text { Artificially } \\
\text { inoculated } \\
\text { strawberries }\end{array}$ & $\begin{array}{l}\text { Approximately a } 4.3-4.7-\log \text { CFU/strawberry of all } \\
\text { examined bacteria was achieved by treatment with } 5 \mathrm{mg} / \mathrm{L} \\
\mathrm{ClO}_{2} \text { for } 10 \mathrm{~min}\end{array}$ & $\begin{array}{l}\text { (Mahmoud, Bhagat, \& } \\
\text { Linton, 2007) }\end{array}$ \\
\hline PAA & $\begin{array}{l}\text { Concentration: } \\
\mathrm{mg} / \mathrm{mL} \\
\text { Exposure time: } 10-120 \mathrm{~s} \\
\text { Temperature: } 4-40^{\circ} \mathrm{C}\end{array}$ & TMC & Fresh strawberries & $\begin{array}{l}\text { After modelling the results, two optimization scenarios } \\
\text { were studied: OP1 }\left(100 \mathrm{mg} / \mathrm{L}, 50 \mathrm{~s} \text {, and } 24{ }^{\circ} \mathrm{C}\right) \text { and OP } 2 \\
\left(20 \mathrm{mg} / \mathrm{L}, 52 \mathrm{~s} \text {, and } 18{ }^{\circ} \mathrm{C}\right) \text {. OP } 1 \text { and OP } 2 \text { reached } \\
\text { reductions of } 1.8-\text { and } 0.8-\log \mathrm{CFU} / \mathrm{g} \text { of microbial count, } \\
\text { respectively. OP } 2 \text { conditions resulted in better sensory } \\
\text { attributes and the economic convenience of lesser PAA }\end{array}$ & $\begin{array}{l}\text { (van de Velde, et al., } \\
2014 \text { ) }\end{array}$ \\
\hline
\end{tabular}




\begin{tabular}{|c|c|c|c|c|c|}
\hline & & & & consumption. & \\
\hline $\begin{array}{l}\text { Strawberry- } \\
\text { flavoured } \\
\text { vinegar } \\
\text { Acetic acid }\end{array}$ & $\begin{array}{l}\text { Concentration: } 0.000- \\
0.225 \%\end{array}$ & B. cinerea & $\begin{array}{l}\text { Inoculated } \\
\text { strawberries }\end{array}$ & $\begin{array}{l}\text { Baby corn fermented vinegar containing } 0.225 \% \text { acetic } \\
\text { acid completely inhibited the growth of } B \text {. cinerea. Shelf } \\
\text { life at } 4{ }^{\circ} \mathrm{C} \text { of strawberries sprayed with vapour of } \\
\text { strawberry-flavoured vinegar was extended to } 7 \text { days } \\
\text { while that of fruit exposed to liquid vinegar was extended } \\
\text { to } 11 \text { days. }\end{array}$ & $\begin{array}{l}\text { (Krusong, Jindaprasert, } \\
\text { Laosinwattana, \& } \\
\text { Teerarak, 2015) }\end{array}$ \\
\hline $\begin{array}{l}\text { Acetic acid } \\
\text { vapour }\end{array}$ & $\begin{array}{l}\text { (i) Application at } 2 \mathrm{mg} / \mathrm{L} \\
\text { for } 30 \mathrm{~min} \text { once, twice, or } \\
\text { three times; (ii) } 4 \mathrm{mg} / \mathrm{L} \\
\text { for } 30 \mathrm{~min} \text {; (iii) } 6 \mathrm{mg} / \mathrm{mL} \\
\text { for } 30 \mathrm{~min}\end{array}$ & B. cinerea and microflora & Fresh strawberries & $\begin{array}{l}\text { Triple fumigation with } 2 \mathrm{mg} / \mathrm{L} \text { acetic acid vapour was } \\
\text { found to be most effective treatment resulting in a } 56 \% \\
\text { reduction of decay. Alternatively, a single treatment with } \\
6 \mathrm{mg} / \mathrm{L} \text { AA vapour resulted in a } 44 \% \text { reduction of decay. } \\
\text { The aerobic mesophilic bacteria plate count was only } \\
\text { slightly affected by fumigation. Applying } 3 \mathrm{mg} / \mathrm{L} \text { acetic } \\
\text { acid vapour for } 30 \text { min reduced mould counts from } \\
2.0 \cdot 10^{5} \mathrm{CFU} / \mathrm{g} \text { to less than } 10^{3} \mathrm{CFU} / \mathrm{g} \text {. }\end{array}$ & $\begin{array}{l}\text { (Hassenberg, Geyer, \& } \\
\text { Herppich, 2010) }\end{array}$ \\
\hline $\begin{array}{l}\text { PAA and } \\
\text { hydrogen } \\
\text { peroxide }\end{array}$ & $\begin{array}{l}\text { Sanitizer mixture of PAA } \\
\text { at } 5 \% \text { and hydrogen } \\
\text { peroxide at } 20 \% \text {. } \\
\text { Concentration: } 3.4-116.6 \\
\mu \mathrm{L} \text { sanitizer/L air } \\
\text { chamber. } \\
\text { Treatment time: } 5.7-69.3 \\
\text { min }\end{array}$ & $\begin{array}{l}\text { Total mesophilic } \\
\text { microorganisms and } \\
\text { YMC }\end{array}$ & Strawberries & $\begin{array}{l}\text { Treatment with } 116.6 \mu \mathrm{g} / \mathrm{L} \text { PAA plus hydroxen peroxide } \\
\text { for } 37.5 \mathrm{~min} \text { showed significantly highest efficacy } \\
\text { reducing mesophilic microorganisms by } 3.0-\mathrm{log} \text { units and } \\
\text { YMC by } 1.3-\log \text { reductions. Similarly, treatment with } 100 \\
\mu \mathrm{g} / \mathrm{L} \text { PAA plus hydrogen peroxide for } 60 \mathrm{~min} \text { reached } \\
\text { reductions of } 2.7-\text { and } 3.1-\mathrm{log} \text { units to mesophilic } \\
\text { microorganisms and YMC, respectively. Optimal fogging } \\
\text { conditions achieved were } 10.1 \mathrm{~mL} \text { sanitizer/L air chamber } \\
\text { and } 29.6 \mathrm{~min}\end{array}$ & $\begin{array}{l}\text { (van de Velde, Vaccari, } \\
\text { Piagentini, \& Pirovani, } \\
\text { 2016) }\end{array}$ \\
\hline $\begin{array}{l}\text { SDS and } \\
\text { hydrogen } \\
\text { peroxide }\end{array}$ & $\begin{array}{l}\text { Concentration: } 1 \% \\
\text { hydrogen peroxide and } \\
100 \text { ppm SDS } \\
\text { Treatment time: } 1 \mathrm{~min}\end{array}$ & $\begin{array}{l}\text { E. coli } \quad \mathrm{O} 157: \mathrm{H} 7 \\
\text { Salmonella, and MNV-1 }\end{array}$ & $\begin{array}{l}\text { Artificially } \\
\text { inoculated fresh } \\
\text { strawberries }\end{array}$ & $\begin{array}{l}\text { Treatment with hydrogen peroxide and SDS reduced } E \text {. } \\
\text { coli } \mathrm{O} 157: \mathrm{H} 7 \text { by } 1.9 \text { - and } 1.6-\log \mathrm{CFU} / \mathrm{g} \text {, respectively. }\end{array}$ & (Huang et al., 2015) \\
\hline \begin{tabular}{lr}
\multicolumn{2}{l}{ Chlorinated } \\
water & and \\
levulinic & acid \\
(LVA) & plus
\end{tabular} & $\begin{array}{l}\text { (i) Chlorinated water at } \\
50 \mathrm{ppm} \text {; (ii) } 0.5 \% \text { LVA } \\
\text { plus } 0.5 \% \text { SDS; (iii) } 5 \%\end{array}$ & $\begin{array}{l}\text { Enterococcus faecium, } \\
\text { L. monocytogenes, } \quad S . \\
\text { enterica, } \quad \text { E. coli } \\
\text { O157:H7, E. coli, MNV- }\end{array}$ & Fresh strawberries & $\begin{array}{l}\text { The } 50 \mathrm{ppm} \text { chlorine wash induced } 3.4-\text { and } 1.5-\mathrm{log} \\
\text { reductions for HAV virus and MNV-1, respectively. The } \\
\text { tested bacterial strains showed uniform reductions around } \\
1.6-\log \mathrm{CFU} / \mathrm{mL} \text {. The } 0.5 \% \text { LVA plus } 0.5 \% \text { SDS wash }\end{array}$ & (Zhou et al., 2017) \\
\hline
\end{tabular}




\begin{tabular}{|c|c|c|c|c|c|}
\hline SDS & $\begin{array}{l}\text { LVA plus } 2 \% \text { SDS. } \\
\text { Exposure time: } 2 \mathrm{~min}\end{array}$ & 1 and other viruses. & & $\begin{array}{l}\text { induced } 2.7-\text { and } 1.4-\log \text { reductions HAV and MNV-1, } \\
\text { which were comparable with the reductions induced by } \\
\text { chlorine. For bacteria, over } 2.0-\log \text { reductions were } \\
\text { obtained for E. faecium, L monocytogenes and Salmonella, } \\
\text { while E. coli O157:H7 and E. coli showed reductions of } \\
1.9-\text { and } 1.8-\log \text { CFU/mL. Higher concentration of LVA } \\
\text { plus SDS showed no significantly higher reductions. }\end{array}$ & \\
\hline $\begin{array}{l}\text { Edible coatings } \\
\text { containing allyl } \\
\text { isothiocyanate } \\
\text { (AIT) and } \\
\text { lauric arginate } \\
\text { ester (LAE) }\end{array}$ & 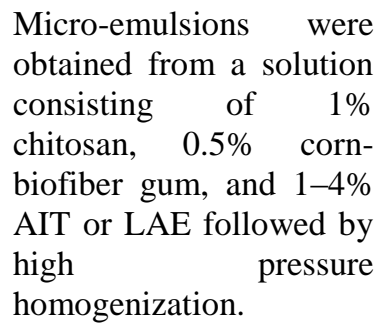 & $\begin{array}{l}\text { S. enterica and E. coli } \\
\text { O157:H7 }\end{array}$ & Strawberries & $\begin{array}{l}\text { LAE films reduced the cell populations to approximately } \\
4.0 \text {-log on strawberries at day } 1 \text { and maintained them at } \\
\text { this level through day } 5 \text {. AIT films reduced the } \\
\text { populations by } 1.0-\log \text { at day } 1 \text {, but continuously reduced } \\
\text { the populations to } 2.8-\log \text { after } 5 \text { days. }\end{array}$ & $\begin{array}{l}\text { (Guo, Yadav, \& Jin, } \\
\text { 2017) }\end{array}$ \\
\hline $\begin{array}{l}\text { Edible coatings } \\
\text { containing } \\
\text { thymol or } \\
\text { carvacrol }\end{array}$ & $\begin{array}{l}\text { Edible coatings evaluated } \\
\text { contained cassava starch, } \\
\text { chitosan, and either } \\
\text { LGRA106 (thymol at } \\
59.26 \% \text { ) or LGRA107 } \\
\text { (carvacrol at } 43.24 \%)\end{array}$ & $\begin{array}{l}\text { YMC, Pseudomonas } \\
\text { aeruginosa, S. aureus, B. } \\
\text { cereus, B. subtilis, } \\
\text { Serratia, marcescens, E. } \\
\text { coli, E. faecalis, and } S . \\
\text { enteriditis }\end{array}$ & Strawberries & $\begin{array}{l}\text { The best formulation of edible coating ( } 1.6 \% \text { of cassava } \\
\text { starch, } 0.6 \% \text { chitosan and } 2.4 \% \text { LGRA } 106 \text { genotype) } \\
\text { remained below the maximum limit recommended for } \\
\text { total psychrophilic aerobic bacteria, YMC in strawberries } \\
\text { during storage at } 4{ }^{\circ} \mathrm{C} \text { for } 7 \text { days. Yeast and mould counts } \\
\text { and total psychrophilic aerobic bacteria decreased from } \\
1.7 \cdot 10^{3} \text { to } 6 \cdot 10^{1} \mathrm{CFU} / \mathrm{g} \text { and from } 1.5 \cdot 10^{2} \text { to below } 10 \\
\mathrm{CFU} / \mathrm{g} \text {, respectively. }\end{array}$ & (Azevedo et al., 2014) \\
\hline $\begin{array}{l}\text { Thiabendazole } \\
\text { and cell-free } \\
\text { supernatant } \\
\text { obtained from } \\
\text { Bacillus } \\
\text { subtilis } \text { ET-1 }\end{array}$ & $\begin{array}{l}\text { The cell-free supernatant } \\
\text { obtained from } B \text {. subtilis, } \\
\text { Thiabendazole, and water } \\
\text { were uniformly applied } \\
\text { as a spray on the } \\
\text { strawberry surface. }\end{array}$ & $\begin{array}{l}\text { B. cinerea and } \\
\text { Penicillium digitatum }\end{array}$ & $\begin{array}{l}\text { Lemon and } \\
\text { strawberry }\end{array}$ & $\begin{array}{l}\text { Supernatant treatment of strawberry fruit reduced the } \\
\text { incidence of disease from } 96.4 \% \text { to } 22.3 \% \text {. The } \\
\text { percentage of surface area covered by gray mould was } \\
\text { strongly reduced in treated strawberries when compared to } \\
\text { the positive control. There were no disease incidences or } \\
\text { decay signs in negative and chemical control. }\end{array}$ & $\begin{array}{l}\text { (Ambrico \& Trupo, } \\
\text { 2017) }\end{array}$ \\
\hline
\end{tabular}




\section{Table 2. Overview of physical technologies used alone or in combination with chemical sanitizers for the control of microorganisms on}

\section{strawberries and products derived thereof.}

\begin{tabular}{|c|c|c|c|c|c|}
\hline Technology & $\begin{array}{l}\text { Microorganisms } \\
\text { evaluated }\end{array}$ & Food matrix & Conditions studied & Main outcomes & Reference \\
\hline UV radiation & $\begin{array}{l}\text { E. coli } \mathrm{O} 157: \mathrm{H} 7 \text { and } \\
\text { S. enterica }\end{array}$ & $\begin{array}{l}\text { Fresh } \\
\text { strawberries }\end{array}$ & $\begin{array}{l}\text { Intensity: } 3-72 \mathrm{~J} / \mathrm{cm}^{2} \\
\text { Treatment time: } 5-60 \mathrm{~s} \text {. }\end{array}$ & $\begin{array}{l}\text { Maximum reductions of E. coli } \mathrm{O} 157: \mathrm{H} 7 \text { and Salmonella } \\
\text { were } 3.9 \text { and } 3.4 \log \mathrm{CFU} / \mathrm{g} \text {, respectively and were } \\
\text { achieved after } 60 \mathrm{~s} \text { and } 72 \mathrm{~J} / \mathrm{cm}^{2} \text {. }\end{array}$ & (Bialka \& Demirci, 2008) \\
\hline UV radiation & TMC and YMC & $\begin{array}{l}\text { Strawberry } \\
\text { juice }\end{array}$ & $\begin{array}{l}\text { Intensity: } 254 \mathrm{~nm}, 25^{\circ} \mathrm{C} \\
\text { Treatment time: } 15-60 \\
\text { min }\end{array}$ & $\begin{array}{l}\text { Significant reduction by } 2-\log \text { cycles in aerobic plate } \\
\text { count as well as in total yeast and mould counts. }\end{array}$ & (Bhat, et al., 2015) \\
\hline UV radiation & TMC and YMC & $\begin{array}{l}\text { Strawberry } \\
\text { nectar }\end{array}$ & $\begin{array}{l}\text { Intensity: } 230-2066 \mathrm{~J} / \mathrm{L} \\
\text { at } 8-10^{\circ} \mathrm{C} \\
\text { Flow rate: } 4000 \mathrm{~L} / \mathrm{h} \\
\text { Contact time: } 0-12 \mathrm{~min}\end{array}$ & $\begin{array}{l}\text { Maximum reductions of TMC and YMC were } 1.3-\text { and } \\
2.4-\log \mathrm{CFU} / \mathrm{mL} \text {. Authors suggested different doses for } \\
\text { different products and therefore, the need for optimizing } \\
\text { treatments depending on each product. }\end{array}$ & (Keyser, et al., 2008) \\
\hline $\begin{array}{l}\text { Combinations of } \\
\text { UV radiation, } \\
\text { IPL, and heat }\end{array}$ & Innoculated $B$. cinerea & $\begin{array}{l}\text { Fresh } \\
\text { strawberries }\end{array}$ & $\begin{array}{l}\text { Intensity: } 30 \mu \mathrm{s} \text { pulses, } \\
15 \mathrm{~Hz} \text { for IPL treatment; } \\
0.5-1.0 \mathrm{~kJ} / \mathrm{m}^{2} \text { for } \mathrm{UV} \\
\text { treatment, and } 40-45{ }^{\circ} \mathrm{C} \\
\text { for heat treatments. } \\
\text { Treatment time: } 40-250 \mathrm{~s} \\
\text { for IPL, } 3-15 \mathrm{~min} \text { for } \\
\text { heat treatment }\end{array}$ & $\begin{array}{l}\text { Short thermal treatments combined with IPL resulted in } \\
\text { reduced fungal development. Combining two } \\
\text { illumination treatments did not cause a significant } \\
\text { decrease in fungal development. However, the most } \\
\text { intense conditions increased the period before the first } \\
\text { observation of fungal growth by } 1 \text { day. }\end{array}$ & $\begin{array}{l}\text { (Marquenie, Michiels, Van } \\
\text { Impe, Schrevens, \& Nicolaï, } \\
\text { 2003) }\end{array}$ \\
\hline IPL & $\begin{array}{l}\text { Postharvest disease } \\
\text { assessed by incidence } \\
\text { (visually recorded) }\end{array}$ & $\begin{array}{l}\text { Fresh } \\
\text { strawberries }\end{array}$ & $\begin{array}{l}\text { Intensity: } 2.4-47.8 \mathrm{~J} / \mathrm{cm}^{2} \\
\text { Treatment time: } 2-40 \mathrm{~s}\end{array}$ & $\begin{array}{l}\text { The incidence of postharvest moulds on strawberry fruits } \\
\text { was reduced by over } 16-42 \% \text { after IPL treatment. }\end{array}$ & (Duarte-Molina, et al., 2016) \\
\hline
\end{tabular}




\begin{tabular}{|c|c|c|c|c|c|}
\hline WPL & $\begin{array}{lr}\text { E. coli } & \mathrm{O} 157: \mathrm{H} 7, \\
\text { Salmonella, } & \text { and } \\
\text { MNV-1 } & \end{array}$ & $\begin{array}{l}\text { Fresh } \\
\text { strawberries } \\
\text { and } \\
\text { raspberries }\end{array}$ & $\begin{array}{l}\text { Intensity: } 4.8-63.2 \mathrm{~J} / \mathrm{cm}^{2} \\
\text { combined with chemical } \\
\text { sanitizers } \\
\text { Treatment time: } 5-60 \mathrm{~s}\end{array}$ & $\begin{array}{l}\text { E. coli inactivation was time-dependent. Processing for } \\
60 \mathrm{~s} \text { reduced } E \text {. coli } \mathrm{O} 157: \mathrm{H} 7 \text { from strawberries and } \\
\text { raspberries by } 2.4-\text { and } 4.5-\log \mathrm{CFU} / \mathrm{G} \text {, respectively. } \\
\text { Combinations with chemical sanitizers resulted in higher } \\
\text { efficacy in reducing } E \text {. coli. For decontamination of } \\
\text { MNV- } 1 \text {, WPL processing for } 60 \mathrm{~s} \text { reduced the viral titers } \\
\text { on strawberries and raspberries by } 1.8 \text { - and } 3.6-\log \text { units, } \\
\text { respectively. }\end{array}$ & (Huang \& Chen, 2015) \\
\hline HPP & TMC and YMC & $\begin{array}{l}\text { Strawberry } \\
\text { puree }\end{array}$ & $\begin{array}{l}\text { Intensity: } 300 \text { or } 500 \\
\mathrm{MPa}\left(0 \text { or } 50^{\circ} \mathrm{C}\right) . \\
\text { Treatment time: } \\
15 \text { min }\end{array}$ & $\begin{array}{l}\mathrm{HPP} \text { at } 500 \mathrm{MPa} \text { at either } 0 \text { or } 50{ }^{\circ} \mathrm{C} \text { reduced YMC from } \\
4.6 \text { and } 3.8 \log \mathrm{CFU} / \mathrm{g} \text { to }<1 \log \mathrm{CFU} / \mathrm{g} \text {. HPP at } \\
300 \mathrm{MPa} \text { allowed a reduction of } 2.6 \text { and } 0.5 \log \mathrm{CFU} / \mathrm{g} \\
\text { for YMC, respectively. HPP at } 50^{\circ} \mathrm{C} \text { allowed a } \\
\text { reduction of } 4.7 \log \mathrm{CFU} / \mathrm{g} \text { in the TMC. No reductions } \\
\text { were observed at } 0{ }^{\circ} \mathrm{C} \text {. }\end{array}$ & (Marszałek, et al., 2015b) \\
\hline HPP & $\begin{array}{l}\text { E. coli } \mathrm{O} 157: \mathrm{H} 7 \text { and } \\
\text { non-O157 STEC. }\end{array}$ & $\begin{array}{l}\text { Strawberry } \\
\text { puree }\end{array}$ & $\begin{array}{l}\text { Intensity: } 150-450 \mathrm{MPa} \\
\text { Treatment time: } 5-30 \\
\text { min }\end{array}$ & $\begin{array}{l}\mathrm{HPP} \text { at } 350 \mathrm{MPa} \text { for more than } 5 \mathrm{~min} \text { allowed a } \\
\text { reduction of 6-log CFU/g on non-O157 STEC. }\end{array}$ & (Hsu, et al., 2014) \\
\hline HPP & $\begin{array}{l}\text { Spores of } \\
\text { Byssochlamys nivea }\end{array}$ & $\begin{array}{l}\text { Strawberry } \\
\text { puree }\end{array}$ & $\begin{array}{l}\text { Intensity: } 600 \mathrm{MPa} \\
\text { Treatment time: }\end{array}$ & $\begin{array}{l}\text { The } 600 \mathrm{MPa} \text { HPP-thermal showed the best technique } \\
\text { among HPTP, TS and thermal methods, for the } \\
\text { inactivation of moulds' ascospores. For a } 75^{\circ} \mathrm{C} \text { and } \\
10 \text { min HPTP process, } 1.4 \log \text { reductions in ascospores } \\
\text { of } B \text {. nivea were obtained. While after } 40 \text { min, reaching } \\
3.4 \mathrm{log} \text { unit reductions for B. nivea. On the other hand, } \\
\text { thermal treatment caused a steady and slow increase in } \\
\text { the spore numbers. Although } \geq 12 \text { min }(B \text {. nivea) TS } \\
\text { processes showed higher inactivation }(0.5 \log ) \text { than } \\
\text { thermal (no inactivation). }\end{array}$ & $\begin{array}{l}\text { (Milani, Ramsey, \& Silva, } \\
\text { 2016) }\end{array}$ \\
\hline HPP & $\begin{array}{l}\text { Moulds, yeasts, } \\
\text { Alicyclobacillus }\end{array}$ & $\begin{array}{l}\text { Fruits } \\
\text { including }\end{array}$ & Intensity: $600 \mathrm{MPa}$ & $\begin{array}{l}\text { B. nivea was more resistant to HPP combined with } \\
\text { temperature than } N \text {. fischeri. For a } 75{ }^{\circ} \mathrm{C} \text { and } 10 \mathrm{~min}\end{array}$ & (Milani \& Silva, 2017) \\
\hline
\end{tabular}




\begin{tabular}{|c|c|c|c|c|c|}
\hline & $\begin{array}{l}\text { acidoterrestris, B. } \\
\text { nivea, Neosartorya } \\
\text { fischery, and spores of } \\
\text { Clostridium } \\
\text { perfringenses and } \\
\text { Bacillus cereus }\end{array}$ & strawberries & $\begin{array}{l}\text { Temperature: } 70 \text { or } 75^{\circ} \mathrm{C} \\
\text { Treatment time: } \quad 1-40 \\
\text { min }\end{array}$ & $\begin{array}{l}\text { process, } 1.4-\log \text { reductions in ascospores of B. nivea and } \\
3.3-\log \text { reductions in ascospores of } N \text {. fischeri were } \\
\text { obtained. HPP combined with temperature reduced the } \\
\text { ascospores steadily, reaching 3.4-log for B. nivea and } \\
\text { 5.2-log for N. fischeri after } 40 \text { min. }\end{array}$ & \\
\hline HPP & MNV-1 & $\begin{array}{l}\text { Fresh } \\
\text { strawberries } \\
\text { and } \\
\text { strawberry } \\
\text { puree }\end{array}$ & $\begin{array}{l}\text { Intensity: } 350 \mathrm{MPa}(0-20 \\
\left.{ }^{\circ} \mathrm{C}\right) \\
\text { Treatment time: } 2 \mathrm{~min}\end{array}$ & $\begin{array}{l}\text { Pressure cycling offered no distinct advantage over } \\
\text { continuous HPP. When operating in a dry state, lower } \\
\text { temperatures resulted in increased inactivation of MNV- } \\
1 \text {. Treatment for } 2 \text { min at either } 0 \text { or } 20^{\circ} \mathrm{C} \text { reduced the } \\
\text { titer of MNV- } 1 \text { by } 4.4 \text { and } 0.5 \log \text {, respectively. In wet } \\
\text { state, operating at } 300 \mathrm{MPa} \text { and } 0{ }^{\circ} \mathrm{C} \text { achieved } 2.9 \log \\
\text { reductions of MNV-1. }\end{array}$ & (Huang, et al., 2014) \\
\hline HPP & $\begin{array}{l}\text { E. coli } \mathrm{O} 157: \mathrm{H} 7 \text { and } \\
\text { Salmonella spp }\end{array}$ & $\begin{array}{l}\text { Frozen } \\
\text { strawberry } \\
\text { puree }\end{array}$ & $\begin{array}{l}\text { Intensity: } 200-500 \mathrm{MPa} \\
\left(21^{\circ} \mathrm{C}\right) \\
\text { Treatment time: } 2 \mathrm{~min}\end{array}$ & $\begin{array}{l}\mathrm{HPP} \text { at } 450 \mathrm{MPa} \text { for } 2 \text { min was able to eliminate both } \\
\text { pathogens. Frozen storage at }-18{ }^{\circ} \mathrm{C} \text { after HPP enhance } \\
\text { the inactivation of both pathogens. Natural YMC were } \\
\text { effectively reduced by HPP at } 300 \mathrm{MPa} \text { for } 2 \mathrm{~min} \text {. }\end{array}$ & (Huang, et al., 2013) \\
\hline HPP & MNV-1 & $\begin{array}{l}\text { Strawberry } \\
\text { puree and } \\
\text { water }\end{array}$ & $\begin{array}{l}\text { Intensity: } 200-600 \mathrm{MPa} \\
\text { Treatment time: } 2.5-10.0 \\
\text { min }\end{array}$ & $\begin{array}{l}\text { The reduction in MNV-1 infectivity achieved was } \\
\text { pressure- and matrix-dependent. HPP at } 400 \text { MPa for } 2.5 \\
\text { min proved to be sufficient for inactivation of MNV-1 } \\
\text { with over } 99.9 \% \text { reduction. }\end{array}$ & (Mosqueda-Melgar, et al., 2012) \\
\hline PEFs & $\begin{array}{l}\text { E. coli } \mathrm{O} 157: \mathrm{H} 7 \text { and } \\
\text { Salmonella Enteritidis }\end{array}$ & $\begin{array}{l}\text { Fruit juices } \\
\text { including } \\
\text { juice }\end{array}$ & $\begin{array}{l}\text { Intensity: } 35 \quad \mathrm{kV} / \mathrm{cm} \\
\text { combined with chemical } \\
\text { sanitizers } \\
\text { Treatment time: } 500- \\
2000 \mu \mathrm{s}\end{array}$ & $\begin{array}{l}\text { S. Enteritidis and E. coli } \mathrm{O} 157: \mathrm{H} 7 \text { were reduced by more } \\
\text { than 5-log units in orange juice treated by PEFs; whereas } \\
\text { strawberry, apple, and pear juices were pasteurized when } \\
\text { the PEFs were combined with chemical sanitizers. }\end{array}$ & (Mosqueda-Melgar, et al., 2008) \\
\hline PEFs & $\begin{array}{l}\text { E. coli and E. coli } \\
\text { O157:H7 }\end{array}$ & $\begin{array}{l}\text { Strawberry } \\
\text { juice }\end{array}$ & $\begin{array}{lr}\text { Intensity: } & 18.6 \quad \mathrm{kV} / \mathrm{cm} \\
\text { combined } & \text { with } \\
\text { antimicrobials }\left(45-55^{\circ} \mathrm{C}\right)\end{array}$ & $\begin{array}{l}\text { Inactivation of } E . \text { coli at } 45,50 \text {, and } 55^{\circ} \mathrm{C} \text { were } 2.86 \text {, } \\
3.12 \text {, and } 3.79 \log \mathrm{CFU} / \mathrm{mL} \text {. Inactivation of } E \text {. coli } \\
\mathrm{O} 157: \mathrm{H} 7 \text { under the same conditions were } 3.09,4.08 \text {, and }\end{array}$ & (Gurtler, et al., 2011) \\
\hline
\end{tabular}




\begin{tabular}{|c|c|c|c|c|c|}
\hline & & & Treatment time: $150 \mu \mathrm{s}$ & $\begin{array}{l}4.71 \log \mathrm{CFU} / \mathrm{mL} \text {, respectively. Combinations with } \\
\text { chemical treatments enhanced the efficacy of the } \\
\text { process. }\end{array}$ & \\
\hline CAP & $\begin{array}{l}\text { S. enterica serovar } \\
\text { Typhimurium }\end{array}$ & $\begin{array}{l}\text { Inoculated } \\
\text { fresh produce } \\
\text { including } \\
\text { strawberries }\end{array}$ & $\begin{array}{l}\text { Nitrogen-CAP at }<35^{\circ} \mathrm{C} \\
\text { for } 1-15 \mathrm{~min}\end{array}$ & $\begin{array}{l}\text { Maximum reductions were obtained after } 15 \text { min of } \\
\text { treatment and were } 2.7-, 1.7-\text {, and } 0.9-\log \text { for Salmonella } \\
\text { inoculated on lettuce, strawberry, and potato, } \\
\text { respectively. }\end{array}$ & $\begin{array}{l}\text { (Fernandez, Noriega, \& } \\
\text { Thompson, 2013) }\end{array}$ \\
\hline CAP & $\begin{array}{l}\text { Aerobic mesophillic } \\
\text { bacteria and yeast and } \\
\text { mould count }\end{array}$ & $\begin{array}{l}\text { Inoculated } \\
\text { strawberries }\end{array}$ & $\begin{array}{l}\mathrm{CAP} \text { at } 25{ }^{\circ} \mathrm{C} \text { during } 5 \\
\min \end{array}$ & $\begin{array}{l}\text { Treatment for } 5 \text { min resulted in } 2.4-\text { and } 3.3-\log \\
\text { reductions in the total mesophilic and YMC, } \\
\text { respectively. Ozone was generated inside the package } \\
\text { and approximately } 1000 \text { ppm were measured } \\
\text { immediately post-treatment. }\end{array}$ & (Misra, et al., 2014a) \\
\hline CAP & $\begin{array}{l}\text { TMC, YMC, E. coli, } \\
S . \quad \text { enterica serovar } \\
\text { Typhimurium, and } L . \\
\text { monoxytogenes }\end{array}$ & $\begin{array}{l}\text { Inoculated } \\
\text { strawberries }\end{array}$ & Ozone CAP for $10-120 \mathrm{~s}$ & $\begin{array}{l}\text { Reductions in the TMC and YMC were calculated after } \\
60 \mathrm{~s} \text { treatments as } 1.6-\text { and } 5.5-\log \text { CFU/g, respectively. } \\
\text { Treatment for } 120 \mathrm{~s} \text { significantly reduced } L \text {. } \\
\text { monocytogenes inoculated on strawberries. Higher } \\
\text { processing times did not yield any further reductions of } \\
\text { bacteria. }\end{array}$ & (Ziuzina, et al., 2014) \\
\hline $\begin{array}{l}\text { Plasma-activated } \\
\text { water }\end{array}$ & Staphylococcus aureus & $\begin{array}{l}\text { Inoculated } \\
\text { strawberries }\end{array}$ & $\begin{array}{l}\text { Plasma-activated water } \\
\text { with continuous agitation } \\
\text { for 5-15 min }\end{array}$ & $\begin{array}{l}\text { Plasma-activated water treatments achieved initial } \\
\text { reductions of } S \text {. aureus ranging from } 1.6-\text { to } 2.3-\log \text {. } \\
\text { These reductions ranged between } 1.7-\text { to } 3.4-\log \text { after } 4 \\
\text { days of storage. After the storage at } 20{ }^{\circ} \mathrm{C} \text { during } 6 \text { days, } \\
\text { no visual fungal spoilage was detected on treated } \\
\text { strawberries. }\end{array}$ & $\begin{array}{l}\text { (Ma, Wang, Tian, Wang, Zhang, } \\
\text { \& Fang, 2015) }\end{array}$ \\
\hline Ionizing radiation & NoV and Tulane virus & $\begin{array}{l}\text { Fresh } \\
\text { strawberries }\end{array}$ & $\begin{array}{l}\text { E-beam: : } 4-28 \mathrm{kGy} \\
\text { Gamma irradiation: } 2.8 \text { - }\end{array}$ & $\begin{array}{l}\text { A high dose of E-beam treatment was required to } \\
\text { completely abolish the receptor binding ability of human }\end{array}$ & (DiCaprio, et al., 2016) \\
\hline
\end{tabular}




\begin{tabular}{|c|c|c|c|c|c|}
\hline & & & $22.4 \mathrm{kGy}$ & $\begin{array}{l}\text { NoV }(35.3 \mathrm{kGy}) \text { and Tulane virus }(19.5-24.1 \mathrm{kGy}) \text {. Both } \\
\text { human NoV and TV were more susceptible to gamma } \\
\text { irradiation than E-beam. }\end{array}$ & \\
\hline Thermosonication & $\begin{array}{l}\text { Moulds, yeasts, } \\
\text { Alicyclobacillus } \\
\text { acidoterrestris, } \\
\text { nivea, } N . \text { fischery, and } \\
\text { spores of Clostridium } \\
\text { perfringenses and } B . \\
\text { cereus }\end{array}$ & $\begin{array}{l}\text { Strawberry } \\
\text { puree }\end{array}$ & $\begin{array}{l}\text { Intensity: } 24 \mathrm{kHz} \\
\text { Temperature }<78^{\circ} \mathrm{C}\end{array}$ & $\begin{array}{l}\text { Thermosonication showed higher inactivation }(0.5-\log ) \\
\text { than thermal (no inactivation). An unexpected increase in } \\
\text { the spore number up to a maximum of } 1.0-\log \text { for } B \text {. } \\
\text { nivea (at } 5 \mathrm{~min} \text { ) and } 2.4-\log \text { for } N \text {. fisheri (at } 10 \mathrm{~min}) \text {, } \\
\text { prior to inactivation, makes the } 0.33 \mathrm{~W} / \mathrm{mL} 75{ }^{\circ} \mathrm{C} \\
\text { thermosonication process not feasible for commercial } \\
\text { application. }\end{array}$ & (Milani, et al., 2017) \\
\hline US & $\begin{array}{l}\text { TBC and yeast and } \\
\text { mould count }\end{array}$ & $\begin{array}{l}\text { Fresh } \\
\text { strawberries }\end{array}$ & $\begin{array}{l}\text { Intensity: } 20 \mathrm{kHz}, 30-90 \\
\text { W } \\
\text { Treatment time: } \quad 5-10 \\
\text { min }\end{array}$ & $\begin{array}{l}\text { No differences found between US treatments. US } \\
\text { processing reduced the percentage of infected } \\
\text { strawberries after } 1 \text { week of storage at } 4{ }^{\circ} \mathrm{C} \text { from } 6 \% \\
\text { (control) to } 0 \% \text {, and after } 4 \text { weeks of storage from } 17 \% \\
\text { (control) to } 6 \% \text {. }\end{array}$ & $\begin{array}{l}\text { (Aday, Büyükcan, \& Caner, } \\
\text { 2013) }\end{array}$ \\
\hline US & $\begin{array}{l}\text { TBC and yeast and } \\
\text { mould count }\end{array}$ & $\begin{array}{l}\text { Fresh } \\
\text { strawberries }\end{array}$ & $\begin{array}{l}\text { Intensity: } 33 \mathrm{kHz}, 60 \mathrm{~W} \\
\text { Treatment time: } 0-60 \\
\text { min }\end{array}$ & $\begin{array}{l}\text { At the initial day, the bacterial count decreased from } 3.60 \\
\text { to } 2.1-\text { and } 2.0-\log \mathrm{CFU} / \mathrm{g} \text { and yeast and mould count } \\
\text { decreased from } 3.5-\text { to } 2.2-\text { and } 2.0-\log \mathrm{CFU} / \mathrm{g} \text {, after } 40 \\
\text { and } 60 \mathrm{~min} \text { of treatment time, respectively. After storage } \\
\text { of samples at } 4{ }^{\circ} \mathrm{C} \text { for } 15 \text { days, the bacteria load } \\
\text { increased to } 5.9-, 3.9-\text {, and } 5.3-\log \mathrm{CFU} / \mathrm{g} \text {, when samples } \\
\text { were processed for } 0,40 \text {, or } 60 \mathrm{~min} \text {, respectively. Similar } \\
\text { results were observed in yeast and mould, reaching } \\
\text { populations of } 4.8-, 3.5-\text {, and } 4.3-\log \mathrm{CFU} / \mathrm{g} \text {, at } 0,40 \text {, or } \\
60 \text { min treatment time, respectively. }\end{array}$ & (Gani, et al., 2016) \\
\hline US & $\begin{array}{l}\text { Aerobic mesophiles } \\
\text { bacteria and YMC }\end{array}$ & $\begin{array}{l}\text { Fresh } \\
\text { watercress, } \\
\text { parsley, and } \\
\text { strawberries }\end{array}$ & $\begin{array}{l}\text { Intensity: } 45 \mathrm{kHz} \text { in } \\
\text { combination } \quad \text { with } \\
\text { chemical sanitizers } \\
\text { Treatment time: } 10 \mathrm{~min}\end{array}$ & $\begin{array}{l}\text { US combination with sanitizers increased their } \\
\text { efficiency. All evaluated treatments of strawberry } \\
\text { reduced aerobic mesophiles from } 0.7 \text { - to } 4.0-\text { log cycles. } \\
\text { The combined treatment with US and } 40 \mathrm{mg} / \mathrm{L} \text { PAA } \\
\text { resulted in the highest reduction in the natural } \\
\text { contaminant population. }\end{array}$ & (São José, et al., 2015) \\
\hline
\end{tabular}




\begin{tabular}{|c|c|c|c|c|c|}
\hline US & Moulds & $\begin{array}{l}\text { Fresh } \\
\text { strawberries }\end{array}$ & $\begin{array}{l}\text { Intensity: } 20 \mathrm{kHz}, 30 \mathrm{~W} \\
\text { combined with chemical } \\
\text { sanitizers } \\
\text { Treatment time: } 5 \mathrm{~min}\end{array}$ & $\begin{array}{l}\text { All treatments prevented mould growth when compared } \\
\text { to the control. After storage at } 4{ }^{\circ} \mathrm{C} \text {, untreated fruit had } \\
21 \% \text { and } 35 \% \text { decay during the third and fourth weeks, } \\
\text { respectively. }\end{array}$ & (Aday, \& Caner, 2014) \\
\hline US & $\begin{array}{lr}\text { YMC, } & \text { mesophilic } \\
\text { aerobic, lactic } & \text { acid } \\
\text { bacteria, } & \text { and } \\
\text { inoculated } & \text { S. } \\
\text { enterica }\end{array}$ & $\begin{array}{l}\text { Fresh } \\
\text { strawberries }\end{array}$ & $\begin{array}{l}\text { Intensity: } 40 \mathrm{kHz}, 500 \mathrm{~W} \\
\text { combined with chemical } \\
\text { sanitizers } \\
\text { Treatment time: } 5 \mathrm{~min}\end{array}$ & $\begin{array}{l}\text { US increased the effect of all chemical compounds in the } \\
\text { reduction of aerobic and mesophilic bacteria and YMC. } \\
\text { US combined with PAA reduced 1.8-, 2.0-, and 2.0-log } \\
\text { CFU of YMC, mesophilic aerobic bacteria, and lactic } \\
\text { acid bacteria, respectively. US processing reduced } S . \\
\text { enterica population almost } 0.6-\log \text { units. }\end{array}$ & (do Rosário, et al., 2017) \\
\hline US & E. coli $\mathrm{O} 157: \mathrm{H} 7$ & $\begin{array}{l}\text { Inoculated } \\
\text { strawberries }\end{array}$ & $\begin{array}{l}\text { Intensity: } 44-48 \mathrm{kHz} \\
\text { combined with chemical } \\
\text { sanitizers } \\
\text { Treatment time: } 5 \mathrm{~min}\end{array}$ & $\begin{array}{l}\text { US combined with chlorinated water or Acidic EOW } \\
\text { reduced } E \text {. coli } \mathrm{O} 157: \mathrm{H} 7 \text { cells by } 0.7-\text { to } 1.9-\log \mathrm{CFU} / \mathrm{g} \\
\text { depending on the treatment time and treatment solution } \\
\text { temperature. }\end{array}$ & (Hung, et al., 2010) \\
\hline US & $\mathrm{TAB}$ and $\mathrm{YMC}$ & $\begin{array}{l}\text { Fresh fruits } \\
\text { including } \\
\text { strawberries }\end{array}$ & $\begin{array}{l}\text { Intensity: } 40 \mathrm{kHz}, 240 \mathrm{~W} \\
\text { combined with acidic } \\
\text { EOW } \\
\text { Treatment time: } 10 \mathrm{~min}\end{array}$ & $\begin{array}{l}\text { US enhanced the bactericidal activity of acidic EOW } \\
\text { which resulted in } 1.7 \text { - and } 1.2-\log \text { reductions on TAB, } \\
\text { and } 1.5-\text { and } 1.2-\log \text { reductions on YMC, respectively } \\
\text { for cherry tomatoes and strawberries. }\end{array}$ & (Ding, et al., 2015) \\
\hline $\begin{array}{l}\text { US combined } \\
\text { with chemicals }\end{array}$ & $\begin{array}{l}\text { Natural contaminant } \\
\text { population }\end{array}$ & $\begin{array}{l}\text { Watercress, } \\
\text { parsley and } \\
\text { strawberries }\end{array}$ & $\begin{array}{l}\text { Intensity: } 45 \mathrm{kHz}, 10 \\
\text { min. } \\
\text { Combined with: } 20 \text { \& } \\
200 \mathrm{mg} / \mathrm{L} \text { sodium } \\
\text { dichloroisocyanurate, } \\
5 \% \text { hidrogen peroxide, } \\
10 \mathrm{mg} / \mathrm{L} \text { chlorine dioxide } \\
\text { or } 400 \mathrm{mg} / \mathrm{l} \mathrm{PAA}\end{array}$ & $\begin{array}{l}\text { The reductions of aerobic mesophiles in strawberries } \\
\text { ranged between } 0.7-\text { and } 4.0-\log \text { units, being the } \\
\text { combination with PAA the most effective. However, all } \\
\text { treatments with US promoted a reduction in strawberry } \\
\text { firmness }\end{array}$ & (de Sao José \& Vanetti, 2015) \\
\hline
\end{tabular}


Aday, M. S., Buyukcan, M. B., \& Caner, C. (2013). Maintaining the quality of strawberries by combined effect of aqueous chlorine dioxide with modified atmosphere packaging. Journal of Food Processing and Preservation, 37, 568581.

Aday, M. S., Büyükcan, M. B., Temizkan, R., \& Caner, C. (2014). Role of ozone concentrations and exposure times in extending shelf life of strawberry. Ozone: Science \& Engineering, 36, 43-56.

Aday, M. S., \& Caner, C. (2014). Individual and combined effects of ultrasound, ozone and chlorine dioxide on strawberry storage life. LWT - Food Science and Technology, 57, 344-351.

Aday, M. S., Temizkan, R., Büyükcan, M. B., \& Caner, C. (2013). An innovative technique for extending shelf life of strawberry: Ultrasound. LWT - Food Science and Technology, 52, 93-101.

Alexandre, E. M. C., Brandão, T. R. S., \& Silva, C. L. M. (2012). Efficacy of nonthermal technologies and sanitizer solutions on microbial load reduction and quality retention of strawberries. Journal of Food Engineering, 108, 417-426.

Alvarez-Suarez, J. M., Giampieri, F., Tulipani, S., Casoli, T., Di Stefano, G., GonzálezParamás, A. M., Santos-Buelga, C., Busco, F., Quiles, J. L., Cordero, M. D., Bompadre, S., Mezzetti, B., \& Battino, M. (2014). One-month strawberry-rich anthocyanin supplementation ameliorates cardiovascular risk, oxidative stress markers and platelet activation in humans. The Journal of Nutritional Biochemistry, 25, 289-294.

Ambrico, A., \& Trupo, M. (2017). Efficacy of cell free supernatant from Bacillus subtilis ET-1, an Iturin A producer strain, on biocontrol of green and gray mold. Postharvest Biology and Technology, 134, 5-10.

Arango, J., Rubino, M., Auras, R., Gillett, J., Schilder, A., \& Grzesiak, A.L. (2016). Evaluation of chlorine dioxide as an antimicrobial against Botrytis cinerea in California strawberries. Food Packaging and Shelf Life, 9, 45-54.

Artes, F., \& Allende, A. (2014). Minimal processing of fresh fruit, vegetables, and juices. Food, 4, 121-128.

Azevedo, A.N., Buarque, P. R., Cruz, E.M.O., Blank, A. F., Alves, P.B., Nunes, M.L., \& de Aquino Santana, L.C.L. (2014). Response surface methodology for optimisation of edible chitosan coating formulations incorporating essential oil against several foodborne pathogenic bacteria. Food Control, 43, 1-9.

Baert, L., Mattison, K., Loisy-Hamon, F., Harlow, J., Martyres, A., Lebeau, B., Stals, A., Van Coillie, E., Herman, L., \& Uyttendaele, M. (2011). norovirus prevalence in Belgian, Canadian and French fresh produce: a threat to human health? International Journal of Food Microbiology, 151, 261-269.

Ban, Z., Zhang, J., Li, L., Luo, Z., Chen, C., Wang, Y., Yuan, Q., Cai, C., \& Yu, L. (2018). Antioxidant profiles of strawberry (Fragaria ananassa) in relation to fruit maturity and postharvest storage. Journal of Biobased Materials and Bioenergy, 12, 122-128. 
Basu, A., Betts, N.M., Nguyen, A., Newman, E.D., Fu, D., \& Lyons, T.J. (2014). Freeze-dried strawberries lower serum cholesterol and lipid peroxidation in adults with abdominal adiposity and elevated serum lipids. The Journal of nutrition, 144, 830-837.

Basu, A., Nguyen, A., Betts, N.M., \& Lyons, T. J. (2014). Strawberry as a functional food: an evidence-based review. Critical Reviews in Food Science and Nutrition, 54, 790-806.

Bernard, H., Faber, M., Wilking, H., Haller, S., Höhle, M., Schielke, A., Ducomble, T., Siffczyk, C., Merbecks, S., Fricke, G., Hamouda, O., Stark, K., Werber, D., on behalf of the Outbreak Investigation Team. (2014). Large multistate outbreak of norovirus gastroenteritis associated with frozen strawberries, Germany, 2012. Euro Surveillance, 19, 20719.

Beuchat, L.R. (1996). Pathogenic microorganisms associated with fresh produce. Journal of Food Protection, 59, 204-216.

Bhat, R., \& Goh, K.M. (2017). Sonication treatment convalesce the overall quality of hand-pressed strawberry juice. Food Chemistry, 215, 470-476.

Bhat, R., \& Stamminger, R. (2015). Impact of ultraviolet radiation treatments on the physicochemical properties, antioxidants, enzyme activity and microbial load in freshly prepared hand pressed strawberry juice. Food Science and Technology International, 21, 354-363.

Bialasiewicz, P., Prymont-Przyminska, A., Zwolinska, A., Sarniak, A., Wlodarczyk, A., Krol, M., Glusac, J., Nowak, P., Markowski, J., \& Rutkowski, K. P. (2014). Addition of strawberries to the usual diet decreases resting chemiluminescence of fasting blood in healthy subjects-possible health-promoting effect of these fruits consumption. Journal of the American College of Nutrition, 33, 274-287.

Bialka, K. L., \& Demirci, A. (2007). Utilization of gaseous ozone for the decontamination of Escherichia coli O157: H7 and Salmonella on raspberries and strawberries. Journal of Food Protection, 70, 1093-1098.

Bialka, K.L, \& Demirci, A. (2008). Efficacy of pulsed UV-light for the decontamination of Escherichia coli O157:H7 and Salmonella spp. on raspberries and strawberries. Journal of Food Science, 73, M201-M207.

Bórquez, R., Melo, D., \& Saavedra, C. (2015). Microwave-vacuum drying of strawberries with automatic temperature control. Food and Bioprocess Technology, 8, 266-276.

Brodowska, A. J., Nowak, A., \& Śmigielski, K. (2017). Ozone in the food industry: Principles of ozone treatment, mechanisms of action, and applications. An Overview. Critical Reviews in Food Science and Nutrition, IN PRESS, DOI: https://doi.org/10.1080/10408398.2017.1308313

Bruijn, J., Rivas, F., Rodriguez, Y., Loyola, C., Flores, A., Melin, P., \& Borquez, R. (2016). Effect of vacuum microwave drying on the quality and storage stability of strawberries. Journal of Food Processing and Preservation, 40, 1104-1115.

Bursać Kovačević, D., Putnik, P., Dragović-Uzelac, V., Pedisić, S., Režek Jambrak, A., \& Herceg, Z. (2016). Effects of cold atmospheric gas phase plasma on anthocyanins and color in pomegranate juice. Food Chemistry, 190, 317-323. 
Caleb, O.J., Wegner, G., Rolleczek, C., Herppich, W.B., Geyer, M., \& Mahanan, P.V. (2016). Hot water dipping: Impact on postharvest quality, individual sugars, and bioactive compounds during storage of 'Sonata' strawberry. Scientia Horticulturae, 210, 150-157.

Cao, X., Huang, R., \& Chen, H. (2017). Evaluation of pulsed light treatments on inactivation of Salmonella on blueberries and its impact on shelf-life and quality attributes. International Journal of Food Microbiology, 260, 17-26.

Castro, I., Teixeira, J. A., Salengke, S., Sastry, S. K., \& Vicente, A. A. (2004). Ohmic heating of strawberry products: electrical conductivity measurements and ascorbic acid degradation kinetics. Innovative Food Science \& Emerging Technologies, 5, 27-36.

CDC. (2016). 2016-Multistate outbreak of hepatitis A linked to frozen strawberries (Final Update). https://www.cdc.gov/hepatitis/outbreaks/2016/havstrawberries.htm. Accessed 31/08/2018.

Considine, K. M., Kelly, A. L., Fitzgerald, G. F., Hill, C., \& Sleator, R. D. (2008). High-pressure processing-effects on microbial food safety and food quality. FEMS Microbiology Letters, 281, 1-9.

Costa, L. B., Rangel, D. E. N., Morandi, M. A. B., \& Bettiol, W. (2013). Effects of UVB radiation on the antagonistic ability of Clonostachys rosea to Botrytis cinerea on strawberry leaves. Biological Control, 65, 95-100.

de Melo Pereira, G. V., Magalhães, K. T., Lorenzetii, E. R., Souza, T. P., \& Schwan, R. F. (2012). A multiphasic approach for the identification of endophytic bacterial in strawberry fruit and their potential for plant growth promotion. Microbial Ecology, 63(2), 405-417.

Demirci, M., Arici, A., \& Gumus, T. (2003). Presence of patulin in fruit and fruit juices produced in Turkey. Ernahrungs-Umschau, 50, 262-263.

de São José, J. F. B., de Andrade, N. J., Ramos, A. M., Vanetti, M. C. D., Stringheta, P. C., \& Chaves, J. B. P. (2014). Decontamination by ultrasound application in fresh fruits and vegetables. Food Control, 45, 36-50.

de São José, J. F. B., \& Vanetti, M.C.D. (2015). Application of ultrasound and chemical sanitizers to watercress, parsley and strawberry: Microbiological and physicochemical quality. LWT-Food Science and Technology, 63, 946-952.

Delbeke, S., Ceuppens, S., Hessel, C.T., Castro, I., Jacxsens, L., De Zutter, L., Uyttendaele, M. 2015). Microbial safety and sanitary quality of strawberry primary production in Belgium: Risk factors for Salmonella and Shiga toxinproducing Escherichia coli contamination. Applied and Environmental Microbiology, 81, 2562-2570.

Delbeke, S., Hessel, C., Verguldt, E., De Beleyer, A., Clicque, T., Boussemaere, J., Jacxsens, L., \& Uyttendaele, M. (2014). Survival of Salmonella and E. coli O157 on strawberries and basil during storage at different temperatures. In 19th Conference on Food Microbiology, 1, 113-113.

DiCaprio, E., Phantkankum, N., Culbertson, D., Ma, Y., Hughes, J. H., Kingsley, D., Uribe, R. M., \& Li, J. (2016). Inactivation of human norovirus and Tulane virus in simple media and fresh whole strawberries by ionizing radiation. International Journal of Food Microbiology, 232, 43-51. 
Ding, T., Ge, Z., Shi, J., Xu, Y.-T., Jones, C. L., \& Liu, D.-H. (2015). Impact of slightly acidic electrolyzed water (SAEW) and ultrasound on microbial loads and quality of fresh fruits. LWT - Food Science and Technology, 60, 1195-1199.

do Rosário, D. K. A., da Silva Mutz, Y., Peixoto, J. M. C., Oliveira, S. B. S., de Carvalho, R. V., Carneiro, J. C. S., de São José, J. F. B., \& Bernardes, P. C. (2017). Ultrasound improves chemical reduction of natural contaminant microbiota and Salmonella enterica subsp. enterica on strawberries. International Journal of Food Microbiology, 241, 23-29.

Duarte-Molina, F., Gómez, P. L., Castro, M. A., \& Alzamora, S. M. (2016). Storage quality of strawberry fruit treated by pulsed light: Fungal decay, water loss and mechanical properties. Innovative Food Science \& Emerging Technologies, 34, 267-274.

EFSA. (2014). Scientific Opinion on the risk posed by pathogens in food of non-animal origin. Part 2 (Salmonella and Norovirus in berries). EFSA Journal, 12, 37063801.

Fang, X., Pengyu, Z., \& Xiaohu, W. (2013). Comparative study of different preservation methods of strawberry. Journal of Anhui Agricultural Sciences, 3, 115-117.

Fernandez, A., Noriega, E., \& Thompson, A. (2013). Inactivation of Salmonella enterica serovar Typhimurium on fresh produce by cold atmospheric gas plasma technology. Food Microbiology, 33, 24-29.

Fino, V. R., \& Kniel, K. E. (2008). UV light inactivation of hepatitis A virus, Aichi virus, and feline calicivirus on strawberries, green onions, and lettuce. Journal of Food Protection, 71, 908-913.

Forghani, F., Rahman, S., Park, M.-S., Park, J.-H., Park, J., Song, K.-B., \& Oh, D.-H. (2013). Ultrasonication enhanced low concentration electrolyzed water efficacy on bacteria inactivation and shelf life extension on lettuce. Food Science and Biotechnology, 22, 131-136.

Gani, A., Baba, W. N., Ahmad, M., Shah, U., Khan, A. A., Wani, I. A., Masoodi, F. A., \& Gani, A. (2016). Effect of ultrasound treatment on physico-chemical, nutraceutical and microbial quality of strawberry. LWT - Food Science and Technology, 66, 496-502.

Giampieri, F., Alvarez-Suarez, J. M., \& Battino, M. (2014). Strawberry and human health: effects beyond antioxidant activity. Journal of Agricultural and Food Chemistry, 62, 3867-3876.

Giampieri, F., Forbes-Hernandez, T. Y., Gasparrini, M., Alvarez-Suarez, J. M., Afrin, S., Bompadre, S., Quiles, J. L., Mezzetti, B., \& Battino, M. (2015). Strawberry as a health promoter: an evidence based review. Food \& Function, 6, 13861398.

Giampieri, F., Tulipani, S., Alvarez-Suarez, J. M., Quiles, J. L., Mezzetti, B., \& Battino, M. (2012). The strawberry: composition, nutritional quality, and impact on human health. Nutrition, 28, 9-19.

Guentzel, J. L., Callan, M. A., Lam, K. L., Emmons, S. A., \& Dunham, V. L. (2011). Evaluation of electrolyzed oxidizing water for phytotoxic effects and pre-harvest 
management of gray mold disease on strawberry plants. Crop Protection, 30, 1274-1279.

Guo, M., Yadav, M. P., \& Jin, T. Z. (2017). Antimicrobial edible coatings and films from micro-emulsions and their food applications. International Journal of Food Microbiology, 263, 9-16.

Gurtler, J. B., Bailey, R. B., Geveke, D. J., \& Zhang, H. Q. (2011). Pulsed electric field inactivation of E. coli $\mathrm{O} 157: \mathrm{H} 7$ and non-pathogenic surrogate E. coli in strawberry juice as influenced by sodium benzoate, potassium sorbate, and citric acid. Food Control, 22, 1689-1694.

Hashmi, M. S., East, A. R., Palmer, J. S., \& Heyes, J. A. (2013). Pre-storage hypobaric treatments delay fungal decay of strawberries. Postharvest Biology and Technology, 77, 75-79.

Hassenberg, K., Geyer, M., \& Herppich, W. (2010). Effect of acetic acid vapour on the natural microflora and Botrytis cinerea of strawberries. European Journal of Horticultural Science, 75, 141-146.

Heleno, F. F., De Queiroz, M. E. L., Neves, A. A., Freitas, R. S., Faroni, L. R. A., \& De Oliveira, A. F. (2014). Effects of ozone fumigation treatment on the removal of residual difenoconazole from strawberries and on their quality. Journal of Environmental Science and Health, Part B, 49, 94-101.

Hsu, H., Sheen, S., Sites, J., Huang, L., \& Wu, J. S.-B. (2014). Effect of high pressure treatment on the survival of Shiga toxin-producing Escherichia coli in strawberry puree. Food Microbiology, 40, 25-30.

Huang, R., Li, X., Huang, Y., \& Chen, H. (2014). Strategies to enhance high pressure inactivation of murine norovirus in strawberry puree and on strawberries. International Journal of Food Microbiology, 185, 1-6.

Huang, Y., \& Chen, H. (2015). Inactivation of Escherichia coli O157:H7, Salmonella and human norovirus surrogate on artificially contaminated strawberries and raspberries by water-assisted pulsed light treatment. Food Research International, 72, 1-7.

Huang, Y., Ye, M., \& Chen, H. (2013). Inactivation of Escherichia coli O157:H7 and Salmonella spp. in strawberry puree by high hydrostatic pressure with/without subsequent frozen storage. International Journal of Food Microbiology, 160, $337-343$.

Hung, Y. C., Tilly, P., \& Kim, C. (2010). Efficacy of electrolyzed oxidizing (EO) water and chlorinated water for inactivation of Escherichia coli O157: H7 on strawberries and broccoli. Journal of Food Quality, 33, 559-577.

Ilhan, K., \& Karabulut, O. A. (2013). Efficacy and population monitoring of bacterial antagonists for gray mold (Botrytis cinerea Pers. ex. Fr.) infecting strawberries. BioControl, 58, 457-470.

Islam, M. S., Patras, A., Pokharel, B., Wu, Y., Vergne, M. J., Shade, L., Xiao, H., \& Sasges, M. (2016). UV-C irradiation as an alternative disinfection technique: Study of its effect on polyphenols and antioxidant activity of apple juice. Innovative Food Science \& Emerging Technologies, 34, 344-351.

Jensen, B., Knudsen, I. M. B., Andersen, B., Nielsen, K. F., Thrane, U., Jensen, D. F., \& Larsen, J. (2013). Characterization of microbial communities and fungal 
metabolites on field grown strawberries from organic and conventional production. International Journal of Food Microbiology, 160, 313-322.

Johannessen, G. S., Eckner, K. F., Heiberg, N., Monshaugen, M., Begum, M., Økland, M., \& Høgåsen, H. R. (2015). Occurrence of Escherichia coli, Campylobacter, Salmonella and shiga-toxin producing E. coli in Norwegian primary strawberry production. International Journal of Environmental Research and Public Health, 12, 6919-6932.

Juan, C., Oueslati, S., \& Mañes, J. 2016. Evaluation of Alternaria mycotoxins in strawberries: quantification and storage condition. Food Additives and Contaminants: Part A, 33, 861-868.

Kader, A. A. (1991). Quality and its maintenance in relation to the postharvest physiology of strawberry. Quality and its maintenance in relation to the postharvest physiology of strawberry. Timber press, Portland, 145-152.

Keyser, M., Müller, I. A., Cilliers, F. P., Nel, W., \& Gouws, P. A. (2008). Ultraviolet radiation as a non-thermal treatment for the inactivation of microorganisms in fruit juice. Innovative Food Science \& Emerging Technologies, 9, 348-354.

Kim, T.-E., Gil, B., Kim, C.-T., \& Cho, Y.-J. (2017). Enrichment of phenolics in harvested strawberries by High-Pressure treatment. Food and Bioprocess Technology, 10, 222-227.

Knudsen, D. M., Yamamoto, S. A., \& Harris, L. J. (2001). Survival of Salmonella spp. and Escherichia coli O157: $\mathrm{H} 7$ on fresh and frozen strawberries. Journal of Food Protection, 64, 1483-1488.

Kovač, K., Diez-Valcarce, M., Raspor, P., Hernández, M., \& Rodríguez-Lázaro, D. (2012). Effect of high hydrostatic pressure processing on norovirus infectivity and genome stability in strawberry puree and mineral water. International Journal of Food Microbiology, 152(1), 35-39.

Krimm, U., Abanda-Nkpwatt, D., Schwab, W., \& Schreiber, L. (2005). Epiphytic microorganisms on strawberry plants (Fragaria ananassa cv. Elsanta): identification of bacterial isolates and analysis of their interaction with leaf surfaces. FEMS Microbiology Ecology, 53, 483-492.

Krusong, W., Jindaprasert, A., Laosinwattana, C., \& Teerarak, M. (2015). Baby corn fermented vinegar and its vapour control postharvest decay in strawberries. New Zealand Journal of Crop and Horticultural Science, 43, 193-203.

Lafarga, T., Bobo, G., Viñas, I., Collazo, C., \& Aguiló-Aguayo, I. (2018). Effects of thermal and non-thermal processing of cruciferous vegetables on glucosinolates and its derived forms. Journal of Food Science and Technology, 55, 1973-1981.

Laidler, M.R., Tourdjman, M., Buser, G.L., Hostetler, T., Repp, K.K., Leman, R., Samadpour, M., \& Keene, W.E. (2013). Escherichia coli O157:H7 infections associated with consumption of locally grown strawberries contaminated by deer. Clinical Infectious Diseases, 57, 1129-1134.

Leroch, M., Plesken, C., Weber, R. W. S., Kauff, F., Scalliet, G., \& Hahn, M. (2013). Gray mold populations in German strawberry fields are resistant to multiple fungicides and dominated by a novel clade closely related to Botrytis cinerea. Applied and Environmental Microbiology, 79, 159-167. 
Li, D., Butot, S., Zuber, S., PROFEL, \& Uyttendaele, M. 2018. Monitoring of foodborne viruses in berries and consideration on the use of RT-PCR methods in surveillance. Food Control, 89, 235-240.

Li, M., Li, X., Li, J., Ji, Y., Han, C., Jin, P., \& Zheng, Y. (2018). Responses of fresh-cut strawberries to ethanol vapor pretreatment: improved quality maintenance and associated antioxidant metabolism in gene expression and enzyme activity levels. Journal of Agricultural and Food Chemistry, 66, 8362-8390.

Lozowicka, B., Jankowska, M., Hrynko, I., \& Kaczynski, P. (2015). Removal of 16 pesticide residues from strawberries by washing with tap and ozone water, ultrasonic cleaning and boiling. Environmental Monitoring and Assessment, 18, 51-70.

Luksiene, Z., \& Brovko, L. (2013). Antibacterial photosensitization-based treatment for food safety. Food Engineering Reviews, 5, 185-199.

Luksiene, Z., Buchovec, I., \& Viskelis, P. (2013). Impact of high-power pulsed light on microbial contamination, health promoting components and shelf life of strawberries. Food Technology and Biotechnology, 51, 284.

Luksiene, Z., \& Paskeviciute, E. (2011). Novel approach to the microbial decontamination of strawberries: chlorophyllin-based photosensitization. Journal of Applied Microbiology, 110, 1274-1283.

Ma, R., Wang, G., Tian, Y., Wang, K., Zhang, J., \& Fang, J. (2015). Non-thermal plasma-activated water inactivation of food-borne pathogen on fresh produce. Journal of Hazardous Materials, 300, 643-651.

Macori, G., Gilardi, G., Bellio, A., Bianchi, D.M., Gallina, S., Vitale, N., Gullino, M.L., \& Decastelli, L. 2018. Microbiological parameters in the primary production of berries: A pilot study. Foods, 7, 105-120.

Marquenie, D., Michiels, C. W., Van Impe, J. F., Schrevens, E., \& Nicolaï, B. N. (2003). Pulsed white light in combination with UV-C and heat to reduce storage rot of strawberry. Postharvest Biology and Technology, 28, 455-461.

Marszałek, K., Mitek, M., \& Skąpska, S. (2015a). Effect of continuous flow microwave and conventional heating on the bioactive compounds, colour, enzymes activity, microbial and sensory quality of strawberry puree. Food and Bioprocess Technology, 8, 1864-1876.

Marszałek, K., Mitek, M., \& Skąpska, S. (2015b). The effect of thermal pasteurization and high pressure processing at cold and mild temperatures on the chemical composition, microbial and enzyme activity in strawberry purée. Innovative Food Science \& Emerging Technologies, 27, 48-56.

Marszałek, K., Woźniak, Ł., Kruszewski, B., \& Skąpska, S. (2017). The effect of high pressure techniques on the stability of anthocyanins in fruit and vegetables. International Journal of Molecular Sciences, 18, 277-300.

Meireles, A., Giaouris, E., \& Simões, M. (2016). Alternative disinfection methods to chlorine for use in the fresh-cut industry. Food Research International, 82, 7185.

Mezzetti, B., Balducci, F., Capocasa, F., Cappelletti, R., Mazzoni, L., Giampieri, F., \& Battino, M. (2014). Can we breed a healthier strawberry and claim it?. Acta Horticulturae, 117, 7-14. 
Milani, E., \& Silva, F. V. (2017). Comparing high pressure thermal processing and thermosonication with thermal processing for the inactivation of bacteria, moulds, and yeasts spores in foods. Journal of Food Engineering, 214, 90-96.

Milani, E. A., Ramsey, J. G., \& Silva, F. V. (2016). High pressure processing and thermosonication of beer: comparing the energy requirements and Saccharomyces cerevisiae ascospores inactivation with thermal processing and modeling. Journal of Food Engineering, 181, 35-41.

Misra, N. N., Moiseev, T., Patil, S., Pankaj, S. K., Bourke, P., Mosnier, J. P., Keener, K. M. \& Cullen, P. J. (2014a). Cold plasma in modified atmospheres for postharvest treatment of strawberries. Food and Bioprocess Technology, 7, 30453054.

Misra, N. N., Patil, S., Moiseev, T., Bourke, P., Mosnier, J. P., Keener, K. M., \& Cullen, P. J. (2014b). In-package atmospheric pressure cold plasma treatment of strawberries. Journal of Food Engineering, 125, 131-138.

Moreno, J., Simpson, R., Baeza, A., Morales, J., Muñoz, C., Sastry, S., \& Almonacid, S. (2012a). Effect of ohmic heating and vacuum impregnation on the osmodehydration kinetics and microstructure of strawberries (cv. Camarosa). LWT - Food Science and Technology, 45, 148-154.

Moreno, J., Simpson, R., Pizarro, N., Parada, K., Pinilla, N., Reyes, J., \& Almonacid, S. (2012b). Effect of ohmic heating and vacuum impregnation on the quality and microbial stability of osmotically dehydrated strawberries (cv. Camarosa). Journal of Food Engineering, 110, 310-316.

Mosqueda-Melgar, J., Raybaudi-Massilia, R. M., \& Martín-Belloso, O. (2008). Nonthermal pasteurization of fruit juices by combining high-intensity pulsed electric fields with natural antimicrobials. Innovative Food Science \& Emerging Technologies, 9, 328-340.

Mosqueda-Melgar, J., Raybaudi-Massilia, R. M., \& Martín-Belloso, O. (2012). Microbiological shelf life and sensory evaluation of fruit juices treated by highintensity pulsed electric fields and antimicrobials. Food and Bioproducts Processing, 90, 205-214.

Nayak, B., Liu, R. H., \& Tang, J. (2015). Effect of processing on phenolic antioxidants of fruits, vegetables, and grains-a review. Critical reviews in food science and nutrition, 55, 887-918.

Odriozola-Serrano, I., Aguiló-Aguayo, I., Soliva-Fortuny, R., \& Martín-Belloso, O. (2013). Pulsed electric fields processing effects on quality and health-related constituents of plant-based foods. Trends in Food Science \& Technology, 29, 98-107.

Odriozola-Serrano, I., Soliva-Fortuny, R., \& Martín-Belloso, O. (2008). Phenolic acids, flavonoids, vitamin $\mathrm{C}$ and antioxidant capacity of strawberry juices processed by high-intensity pulsed electric fields or heat treatments. European Food Research and Technology, 228, 239.

Oszmiański, J., Lachowicz, S., Gorzelany, J., \& Matłok, N. (2018). The effect of different maturity stages on phytochemical composition and antioxidant capacity of cranberry cultivars. European Food Research and Technology, 244, 705-719. 
Oviedo-Solís, C. I., Sandoval-Salazar, C., Lozoya-Gloria, E., Maldonado-Aguilera, G. A., Aguilar-Zavala, H., Beltrán-Campos, V., Pérez-Vázquez, V., \& RamírezEmiliano, J. (2017). Ultraviolet light-C increases antioxidant capacity of the strawberry (Fragaria x ananassa) in vitro and in high-fat diet-induced obese rats. Food Science \& Nutrition, 5, 1004-1014.

Palumbo, M., Harris, L.J., \& Danyluk, M.D. (2014). Outbreakd of foodborne illness associated with common berries, 1983 through May 2013. University of Florida -IFAS Extension, FHS 13-08, 1-9.

Patras, A., Brunton, N. P., O'Donnell, C., \& Tiwari, B. (2010). Effect of thermal processing on anthocyanin stability in foods; mechanisms and kinetics of degradation. Trends in Food Science \& Technology, 21, 3-11.

Petruzzi, L., Corbo, M. R., Sinigaglia, M., \& Bevilacqua, A. (2017). Chapter 1 Microbial Spoilage of Foods: Fundamentals. In A. Bevilacqua, M. R. Corbo \& M. Sinigaglia (Eds.), The Microbiological Quality of Food (pp. 1-21): Woodhead Publishing.

Predmore, A., Sanglay, G., Li, J., \& Lee, K. (2015). Control of human norovirus surrogates in fesh foods by gaseous ozone and a proposed mechanism of inactivation. Food Microbiology, 50, 118-125.

Rahman, S., Park, J., Song, K. B., Al-Harbi, N. A., \& Oh, D. H. (2012). Effects of slightly acidic low concentration electrolyzed water on microbiological, physicochemical, and sensory quality of fresh chicken breast meat. Journal of Food Science, 77, M35-M42.

Ramos, B., Miller, F. A., Brandão, T. R. S., Teixeira, P., \& Silva, C. L. M. (2013). Fresh fruits and vegetables-An overview on applied methodologies to improve its quality and safety. Innovative Food Science \& Emerging Technologies, 20, 115.

RASFF. (2018a). Foodborne outbreak caused by hepatitis A virus (1B) in frozen strawberries from Poland. https://webgate.ec.europa.eu/rasffwindow/portal/?event=notificationDetail\&NOTIF_REFERENCE=2018.1813. Accessed 05/09/18

RASFF. (2018b). Parasitic infestation with microsporidia (presence of Giardia parasite) of strawberries from Spain. https://webgate.ec.europa.eu/rasffwindow/portal/?event=notificationDetail\&NOTIF_REFERENCE=2016.0484. Accessed 05/09/18

RASFF. (2018c). Thirteen infected with Hepatitis A virus from frozen strawberries. https://www.foodsafetynews.com/2018/07/thirteen-infected-with-hepatitis-avirus-from-frozen-strawberries/. Accessed 05/09/18

Salvador, Â. C., Rocha, S. M., \& Silvestre, A. J. (2015). Lipophilic phytochemicals from elderberries (Sambucus nigra L.): Influence of ripening, cultivar and season. Industrial Crops and Products, 71, 15-23.

Šamec, D., Maretić, M., Lugarić, I., Mešić, A., Salopek-Sondi, B., \& Duralija, B. (2016). Assessment of the differences in the physical, chemical and phytochemical properties of four strawberry cultivars using principal component analysis. Food Chemistry, 194, 828-834. 
São José, J. F. B. d., \& Vanetti, M. C. D. (2015). Application of ultrasound and chemical sanitizers to watercress, parsley and strawberry: Microbiological and physicochemical quality. LWT - Food Science and Technology, 63, 946-952.

Selma, M. V., Allende, A., López-Gálvez, F., Conesa, M. A., \& Gil, M. I. (2008). Disinfection potential of ozone, ultraviolet-C and their combination in wash water for the fresh-cut vegetable industry. Food Microbiology, 25, 809-814.

Stratakos, A. C., Delgado-Pando, G., Linton, M., Patterson, M. F., \& Koidis, A. (2015). Synergism between high-pressure processing and active packaging against Listeria monocytogenes in ready-to-eat chicken breast. Innovative Food Science \& Emerging Technologies, 27, 41-47.

Sulaiman, A., \& Silva, F. V. M. (2013). High pressure processing, thermal processing and freezing of 'Camarosa' strawberry for the inactivation of polyphenoloxidase and control of browning. Food Control, 33, 424-428.

Sulaiman, A., Soo, M. J., Farid, M., \& Silva, F. V. M. (2015). Thermosonication for polyphenoloxidase inactivation in fruits: Modeling the ultrasound and thermal kinetics in pear, apple and strawberry purees at different temperatures. Journal of Food Engineering, 165, 133-140.

Sun, J., Zhai, X., Zhang, Z., Qiu, R., Ou, S., \& Bai, W. (2014). Ultrasonic Assisted Extraction of Anthocyanins from Strawberry. Agricultural Science \& Technology, 15, 1403-1406.

Tomadoni, B., Cassani, L., Viacava, G., Moreira, M. D. R., \& Ponce, A. (2017). Effect of ultrasound and storage time on quality attributes of strawberry juice. Journal of Food Process Engineering, 40, e12533.

Tournas, V.H., \& Katsoudas, E. (2015). Mould and yeast flora in fresh berries, grapes and citrus fruit. International Journal of Food Microbiology, 105, 11-17.

Trinetta, V., Linton, R. H., \& Morgan, M. (2013). The application of high-concentration short-time chlorine dioxide treatment for selected specialty crops including Roma tomatoes (Lycopersicon esculentum), cantaloupes (Cucumis melo ssp. melo var. cantaloupensis) and strawberries (Fragaria $\times$ ananassa). Food Microbiology, 34, 296-302.

Tzortzakis, N., \& Chrysargyris, A. (2017). Postharvest ozone application for the preservation of fruits and vegetables. Food Reviews International, 33, 270-315.

Udompijitkul, P., Daeschel, M.A., Zhao, Y. (2007). Journal of Food Science, 72, M397-M406.

Valdivia-Nájar, C. G., Martín-Belloso, O., \& Soliva-Fortuny, R. (2017). Impact of pulsed light treatments and storage time on the texture quality of fresh-cut tomatoes. Innovative Food Science \& Emerging Technologie, 45, 29-35.

van de Velde, F., Güemes, D. R., \& Pirovani, M. E. (2014). Optimisation of the peracetic acid washing disinfection of fresh-cut strawberries based on microbial load reduction and bioactive compounds retention. International Journal of Food Science \& Technology, 49, 634-640.

van de Velde, F., Piagentini, A. M., Güemes, D. R., \& Pirovani, M. E. (2013). Modelling changes in anthocyanins, total vitamin $\mathrm{C}$ and colour as a consequence of peracetic acid washing disinfection of two cultivars of strawberries for fresh- 
cut processing. International Journal of Food Science \& Technology, 48, 954961.

van de Velde, F., Vaccari, M. C., Piagentini, A. M., \& Pirovani, M. É. (2016). Optimization of strawberry disinfection by fogging of a mixture of peracetic acid and hydrogen peroxide based on microbial reduction, color and phytochemicals retention. Food Science and Technology International, 22, 485495.

Verbeyst, L., Bogaerts, R., Van der Plancken, I., Hendrickx, M., \& Van Loey, A. (2013). Modelling of vitamin $\mathrm{C}$ degradation during thermal and high-pressure treatments of red fruit. Food and Bioprocess Technology, 6, 1015-1023.

Wei, C., Guo, L., \& Lei, X. (2017). Identification and toxin-producing capability of causing-spoilage fungi in strawberry. Journal of Food Safety and Quality, 8, 1721-1726.

Wu, J., Liu, W., Yuan, L., Guan, W.-Q., Brennan, C. S., Zhang, Y.-Y., Zhang, J., \& Wang, Z.-D. (2017). The influence of postharvest UV-C treatment on anthocyanin biosynthesis in fresh-cut red cabbage. Scientific Reports, 7, N5232.

Xie, J., Sun, X., Pan, Y., \& Zhao, Y. (2012). Combining basic electrolyzed water pretreatment and mild heat greatly enhanced the efficacy of acidic electrolyzed water against Vibrio parahaemolyticus on shrimp. Food Control, 23, 320-324.

Xie, Z., Charles, M. T., Fan, J., Charlebois, D., Khanizadeh, S., Rolland, D., Roussel, D., Deschênes, M., \& Dube, C. (2015). Effects of preharvest ultraviolet-C irradiation on fruit phytochemical profiles and antioxidant capacity in three strawberry (Fragaria $\times$ ananassa Duch.) cultivars. Journal of the Science of Food and Agriculture, 95, 2996-3002.

Xie, Z., Fan, J., Charles, M. T., Charlebois, D., Khanizadeh, S., Rolland, D., Roussel, D., \& Zhang, Z. (2016). Preharvest ultraviolet-C irradiation: Influence on physicochemical parameters associated with strawberry fruit quality. Plant Physiology and Biochemistry, 108, 337-343.

$\mathrm{Xu}$, W., Chen, H., \& Wu, C. (2016). Salmonella and Escherichia coli O157:H7 inactivation, color, and bioactive compounds enhancement on raspberries during frozen storage after decontamination using new formula sanitizer washing or pulsed light. Journal of Food Protection, 79, 1107-1114.

Zhang, X., Sun, Y., Yang, Q., Chen, L., Li, W., \& Zhang, H. (2015). Control of postharvest black rot caused by Alternaria alternata in strawberries by the combination of Cryptococcus laurentii and Benzo-(1,2,3)-thiadiazole-7carbothioic acid S-methyl ester. Biological Control, 90, 96-101.

Zhou, Z., Zuber, S., Cantergiani, F., Butot, S., Li, D., Stroheker, T., Devlieghere, F., Lima, A., Piantini, U., \& Uyttendaele, M. (2017). Inactivation of viruses and bacteria on strawberries using a levulinic acid plus sodium dodecyl sulfate based sanitizer, taking sensorial and chemical food safety aspects into account. International Journal of Food Microbiology, 257, 176-182.

Ziuzina, D., Patil, S., Cullen, P. J., Keener, K. M., \& Bourke, P. (2014). Atmospheric cold plasma inactivation of Escherichia coli, Salmonella enterica serovar Typhimurium and Listeria monocytogenes inoculated on fresh produce. Food Microbiology, 42, 109-116. 
Zunino, S. J., Parelman, M. A., Freytag, T. L., Stephensen, C. B., Kelley, D. S., Mackey, B. E., Woodhouse, L. R., \& Bonnel, E. L. (2012). Effects of dietary strawberry powder on blood lipids and inflammatory markers in obese human subjects. British Journal of Nutrition, 108, 900-909. 